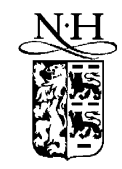

ELSEVIER

\title{
China share issue privatization: the extent of its success ${ }^{2}$
}

\author{
Qian Sun ${ }^{\mathrm{a}}$, Wilson H.S. Tong ${ }^{\mathrm{b}, *}$ \\ ${ }^{a}$ Nanyang Business School, Nanyang Technological University, Singapore 639798, Singapore \\ ${ }^{\mathrm{b}}$ School of Accounting and Finance, Faculty of Business, The Hong Kong Polytechnic University, \\ Hung Hom, Kowloon, Hong Kong, China
}

Received 20 August 2001; accepted 12 November 2002

\begin{abstract}
We evaluate the performance changes of 634 state-owned enterprises (SOEs) listed on China's two exchanges upon share issuing privatisation (SIP) in the period 1994-1998. We find that SIP is effective in improving SOEs' earnings ability, real sales, and workers' productivity but is not successful in improving profit returns and leverage after privatisation. We also find state ownership having negative impacts on firm performance and legal-person ownership having positive impacts on firm performance after SIP, which suggests that legal persons behave differently from the state government. Surprisingly, foreign ownership does not show uniformly strong, positive impacts on firm performance.
\end{abstract}

(C) 2003 Elsevier B.V. All rights reserved.

JEL classification: G34; G39

Keywords: China; Partial privatization; State-owned enterprise; Performance change; Restructuring

\section{Introduction}

Twenty years of economic reform in China have marked success in expanding growth and productivity. One major component of this huge economic restructuring process is the reform of state-owned enterprises (SOEs). The reform has successfully brought down the SOE share in China's gross domestic product from $77.6 \%$ to less

\footnotetext{
${ }^{2}$ We are grateful to the anonymous referee for the extensive detailed comments and suggestions, which substantially improve the quality of the paper. Any errors remain our own.

*Corresponding author. Tel.: + 852-2766-4399; fax: + 852-2774-9364.

E-mail address: acwtong@inet.polyu.edu.hk (W.H.S. Tong).
} 
than $30 \%$ during this period. Yet, SOEs still provide about $40 \%$ of urban employment and over $30 \%$ of the SOEs are still losing money. In 1998, Premier Zhu Rongji set a three-year timeframe for basically finishing the SOE reform process. According to some casual statistics, such a target seems to have been reached. 4,000 large- and medium-sized SOEs have been restructured. Most of the loss-generating, medium-to-large SOEs have worked their way out of difficulty. The number of money-losing SOEs dropped from 6,599 in 1997 to 3,463 by November 2000 (Li, 2001). On the other hand, $66.5 \%$ of SOEs were profitable with total profit of Renminbi 239.2 billion in year 2000, which is a $140 \%$ increase over 1999 . Yet, these profits are partly achieved through heavy government interventions. For instance, the government has directly injected Renminbi 360 billion into SOEs from 1997 to 2000 and imposed monetary and statutory policies such as interest cut, debt-equity swap, and debt write-off to reduce SOEs' heavy debt burden. It is estimated that a series of interest rate cuts in recent years has reduced SOEs' financing costs by Renminbi 260 billion. The debt-equity swap amount totaled Renminbi 112 billion and the debt write-off amount from 1996 to 1999 summed to Renminbi 150 billion (Lianhe Zaobao, July 31, 2001, p. 28). Hence, it is interesting to see in what sense and to what extent China's SOE privatization is successful.

In this paper, we search for answers by evaluating the performance changes of SOEs listed on China's two exchanges upon share issue privatisation (SIP), which has become an important measure taken by the Chinese government in the last decade to reform SOEs. As such, our study contributes to the privatization literature. Despite the large volume of literature on SIP and its impact on firm performance across both market economies and transitional economies, there is no similar, comprehensive study on China. Megginson and Netter (2001) and Djankov and Murrell (2000) provide comprehensive surveys on western-style privatization and privatization in Eastern Europe and the former Soviet republics, respectively. Also, there are only limited empirical studies on China's SOE reform and the results are mixed. Some studies show that SOE's productivity has been significantly improved by the introduction of certain elementary incentives in the 1980s (Groves et al., 1994; Cornelli and Li, 1997). Others show that the reform is far from successful (Lin et al., 1998). In addition, some people argue that China privatization is "nothing but a logo" or just "old wine in new bottles" (Xu and Wang, 1997).

This is an awkward omission as China is too important a country to be neglected. China is the largest socialist economy and the second largest economy in the world on a purchasing power basis only after the US. China is expected, for the first time, to overtake the United States and become the largest foreign direct investment (FDI) recipient country in the world this year, as predicted in the United Nations Conference on Trade and Development (UNCTAD). Nearly \$500 billion in FDI has flooded the country during the past two decades. China has been growing more rapidly than western economies since 1978 and is expected to be a dominant figure in the world economy in coming decades.

Furthermore, China privatisation program differs in key respects from many other countries. Not following the approaches of privatization used in market economies and the mass privatization tried in Lithuania, Poland, Czechoslovakia, Mongolia, 
and Russia, China developed its own path through "crossing the river by touching stones." Lipton et al. (1990) and Boycko et al. (1994) have analysed mass privatization programs. Serious empirical studies that we are aware of are Pohl et al. (1997) on Eastern Europe, Frydman et al. (1996), and Barberis et al. (1996) on Russia, Hingorani et al. (1997) on Czechoslovakia, and Dyck (1997) on East Germany. Biais and Perotti (2002) have an interesting model on politically motivated privatization that is helpful to understand the privatization programs in Eastern Europe. The reform in China has proceeded without complete market liberalization or democratization. The government has played an important role throughout the reform. Some economists term it a "helping-hand model" (Frye and Shleifer, 1997), in which bureaucrats are intimately involved in promoting private activity. In fact, the official term used in China is not "privatization" but "share ownership scheme." Privatization explicitly assumes capitalistic private ownership whereas under the share ownership scheme, as long as the state still holds some shares of the SOE (partial privatization in the western terminology), it somehow still conforms to the communist public ownership principle. Such an ideology of the socialist market economy leads the Chinese government to retain a substantial portion of the ownership of privatized enterprises, especially those medium-to-large ones. To put things in perspective, around 53,000 of 68,000 industrial SOEs are small firms in China (China Daily, October 30, 1997, p. 4). The policy of zhuada fangxiao (to be explained later) in the early 1990s has successfully transformed the failing, smaller SOEs through restructuring, selling, and mergers. The main problem lies with the large and medium-sized SOEs. Share issue privatization (SIP) in the 1990s became a very important strategy in vitalizing them. As mentioned, due to the ideology of the socialist market economy, privatization was only partial with the state being the largest single block holder in most SOEs. There is not even a single listed former SOE that has been completely privatized. As a result, the government still holds shares in listed companies of value equivalent to $17 \%$ of the GDP. Assets owned by the Chinese government were valued at Renminbi 9.88 trillion (US\$1.19 trillion) at the end of 2000 (China Daily, July 30, 2001, p. 2).

Motivated by Shleifer and Vishny (1997) and La Porta et al. (1998, 1999, 2000), we link our investigations with SOEs' ownership and governance structure. Barberis et al. (1996) point out that it is not clear exactly how private ownership leads to greater efficiency. Indeed, existing findings are less than conclusive. Studies like Vining and Boardman (1992), Boardman and Vining (1989), and Megginson et al. (1994) show that government ownership is less efficient than private ownership. The results of Dewenter and Malatesta (2001) strongly support the proposition that government firms display inferior profitability. Several recent papers surveyed in Megginson and Netter (2001) also find empirical evidences in favor of private over public ownership. But studies of Caves and Christensen (1980), Wortzel and Wortzel (1989), Martin and Parker (1995), and Kole and Mulherin (1997) suggest that government ownership is not necessarily less efficient than private ownership. As will be elaborated later, the interesting ownership mix in China's privatization provides us a unique opportunity to examine the issue. We investigate how the differential proportions of ownership structure affect SOEs performance and what governance roles various groups of shareholders can play. 
Based on 634 SOEs that have gone through SIP in the period 1994 to 1998, we find signs of increases in earnings, real sales, and employee productivity of the SOEs after SIP. However, two measures on earnings return do not show improvements. Surprisingly, our leverage measures show higher leverage of our sample SOEs after SIP. In sum, China's privatization has achieved some success on balance but the success is limited when compared with the privatization programs in other countries. We argue that partial privatization could be the reason because state ownership is found to have a negative impact on firm performance upon and after SIP. Furthermore, too much state ownership leads to small and ineffectual foreign ownership. Perhaps foreigners wishing to enter China prefer direct investments or joint venture with SOE partners. As a result, the positive impact of foreign ownership on firm performance after SIP is weaker than expected. Interestingly, legal person ownership, which, as to be explained shortly, is essentially shareholding of other SOEs, has a positive impact on firm's profitability, which suggests that legal persons behave differently from the central government.

Our results have direct implications on the further deepening of China's SOE reform. State ownership in the SIP firms should be reduced from the current level. More shares should be privatized to independent outside institutional investors, be they foreign or domestic. Our study is timely as China's Securities Regulatory Commission (CSRC) has laid out a plan of reducing the proportion of state and legal-person ownership in those privatized SOEs listed in the A-share market but it is facing intense opposition from conservative communists as well as local investors (Hong Kong Economic Journal, June 14, 2001, p. 19).

The rest of the paper proceeds as follows. Section 2 is a short history on China's SOE reform. Section 3 shows the different share structures of SOEs and their roles in corporate governance. Sections 4 and 5 present the empirical results on SOE performance changes and the relationship between ownership mix and firm performance, respectively. Section 6 concludes the paper.

\section{A short history of China's SOE reform}

China's economic and SOE reform process officially began with the third Plenum of the eleventh Central Committee of the Communist Party of China (CPC) in December 1978. According to Liu and Gao (1999), the reform process had four stages. The first stage ran from 1979 to 1983 with the major goal of administrative decentralization and profit retention (fangquan rangli). Instead of centralizing all production and capital allocation decisions as under the old system, a pilot reform program on the expansion of enterprise autonomy was started in late 1978 and SOEs were allowed to retain $3 \%$ of their profits so that there were incentives to improve productivity and efficiency.

Fangquan rangli brought the undesirable consequence of motivating SOEs to bargain with or to hide profits from the government, causing government revenue to decline. The government implemented two new measures. First, SOEs were required to pay taxes instead of turning in profits (ligaishui) so no more bargaining on profit 
sharing is necessary. Second, the funding for SOE capital investments, instead of allocated directly from government financial reserves, had to come through bank loans. This second stage of reform ran from 1983 to 1987. This was called bogaidai (using bank loans to replace government allocation). This policy relieved the government's financial burden and made SOEs more cautious in their use of capital. Unfortunately, this eventually led to the huge "triangular debt" problem that has plagued SOE reform all along. This refers to the fact that a great number of SOEs are in debt to one another. The average total debt ratio of SOEs was as high as $67.9 \%$ in 1994 and $65.1 \%$ in 1996 (Wu, 1997). In 1994, 27.6\% of the SOEs had total debts higher than their total asset values. Another $21.5 \%$ of the SOEs had total debts equal to total equities. The result was that SOEs took in $70 \%$ to $80 \%$ of all bank credit in China and saddled financial institutions with as much as \$200 billion in uncollectible debt. The bad debt was $24 \%$ of all outstanding bank loans, according to Standard \& Poor's estimates (USA Today, September 8,1997, B, 1:2). A recent estimate of Credit Lyonnaise on the total bad loans of the four state banks is $\$ 450$ billion. (Hong Kong Economic Journal, November 11, 2002, p. 9).

Yet, the policies of ligaishui and bogaidai did not help much. Effectively, SOEs used their money to pay the bank interest instead of government taxes. In Chinese accounting, interests (or financial charges) are paid before operating income. Furthermore, they now had an incentive to declare no profit or low profits. The government ended up collecting much less revenue. These factors led to the implementation of the Contractual Management System (chengbaozhi). The government gave SOEs a free hand to run their operations. In return, SOEs had to promise a certain amount of tax to the government. This marked the third stage of the reform process (1987-1992) that focused on the separation of government ownership from control of SOE's operations.

However, the SOEs' obligation was on the profit side, not on the loss side. SOEs were not fully responsible for their losses; the government absorbed some of them in the form of soft budgets. Hard budget constraints could not be strictly imposed on SOEs due to their relatively unfavorable operating conditions. Soft budget constraints gave the SOEs enough leeway not to improve their efficiency. These conditions bore the seeds of the ownership reform of the SOEs.

Lin et al. (1998) discussed four major problems faced by SOEs. SOEs mainly developed out of the necessity of heavy industries. As a result, they are typically capital intensive. Heavy costs of capital and capital obsolescence become an important problem. Second, their products like energy resources, primary materials, and basic life necessities have strategic importance. The product prices are heavily suppressed to facilitate national development plans. Third, they need to bear all social benefits of their employees such as medical insurance, social welfare benefits, housing benefits, and education for children. Redundant workforce is another heavy burden to SOEs. Since SOEs take up most of the employment in China, trimming the workforce would lead to serious unemployment problem.

The 14th Party Congress in October 1992 announced the target of constructing a socialist market economy and establishing a modern corporate system, which spearheaded the fourth stage of the SOE reform, corporatization (gongsihua). In 
December 1994, the State Council proposed a pilot scheme for a few large SOEs. This led to the policy of "taking a firm grip on the large, letting go of the small" (zhuada fangxiao). The government kept a firm grip on one hundred central and 2,600 local, large SOEs. Many weak enterprises were sold off through auctions and corporate transformation while some large- and medium-sized SOEs were transformed into publicly listed firms on the stock market. Only relatively strong SOEs were eligible to go public. At the end of 2000, there were about 1,080 firms listed on China's two national stock exchanges, the Shanghai Stock Exchange (SHSE) and the Shenzhen Stock Exchange (SZSE), which were established in December 1990 and April 1991, respectively. Almost all these firms are former SOEs.

\section{Ownership structure and corporate governance}

There is an extensive literature contrasting firm performance under government ownership and private ownership but relatively few studies focus on mixed ownership situations such as China. Chinese companies have five different types of shares: state shares, legal person shares, employee shares, A shares and B shares. They can also issue shares on overseas exchanges. The recent line of research on law and finance highlights the fact that financial securities are defined not by their implied cash flows but the rights they bring to the holders. And such rights, in turn, are defined by the legal rules and the quality of their enforcement in which the securities are issued (La Porta et al., 1998, 1999, 2000). Given the short history of the China stock market and its governing body CSRC, and the infant stage of the Chinese judicial system and the securities ordinances, it is conceivable that the concepts of shareholder's rights and legal protections of investors are not clear and well defined. As such, it is important to see the ownership and the governance structure of the Chinese SOEs and yet we need to be very careful in interpreting the situation under the context of China.

\subsection{State shares}

State shares exist in China to designate holdings in the SOEs by the central government, local governments, or solely government-owned enterprises. To preserve the economy's socialist structure, SOEs have to issue shares to the government when going public and the proportion is substantial, representing over $30 \%$ of total shares on average. Although it is arguable that state ownership is the origin of immense agency problems in SOEs, it can also play a positive role so that partial privatisation is better than complete privatisation. First, there can be a signaling effect for continued state ownership. Perotti (1995) has a model showing that governments tend to privatize a smaller proportion of such firms at the beginning. Being the largest stakeholder of the partially privatized SOE, the government sends a credible signal to the market that it is not expropriating shareholders' wealth. Schmitz (2000) argues from the incomplete contract approach that partial privatization could well be the optimal ownership structure. Mok and 
Hui (1998) argue that high equity retention by the state lowers the ex-ante uncertainty of domestic investors (and IPO underpricing) because investors interpret that as a sign of the government's confidence in the company, and a business guarantee.

Second, Jefferson (1998) argues from the perspective of viewing SOEs as public goods and that a quick and complete privatization is not desirable. In the absence of a well-functioning property-rights market, privatization can result in the transfer of public assets to private agents who do not use them more efficiently than under state ownership. On the other hand, partial state ownership helps to monitor managers in China's SIP firms. As Stiglitz (1997) points out, there are “...special problems facing developing and transition economies, in which markets are lacking; the markets that do exist may function less effectively, and information problems are more severe than in industrial countries simply because of the rapid change in the economic environment" (p. 15). Indeed, in China the managerial labor market is not well established, the product market does not function well, and the takeover market for firms does not exist at all. There is no significant independent shareholder in China who can provide effective monitoring of management. As a result, managers tend to be opportunistic and seek personal benefit rather than company success. The problem is so serious that it prompts Lin et al. (1998) to argue that expanding the managerial autonomy of SOEs will worsen the agency problems.

Finally, there is a policy role for state ownership in China's SIP firms in the form of government backing or subsidization. SOE reform has been a top priority for China's government since the early 1990s. As the largest blockholder of the privatized SOEs, the Chinese government has put forth a series of policies to revitalize them. These include reducing the tax burden, injecting capital to repay part of the debt, and the recent debt-for-equity swap (zhaizhuangu) measure. To relieve the debt burden of SOEs, the Chinese government has established state-owned asset management companies (AMC). The debt-for-equity swap is a swap of the SOE debts owed to state banks for AMC equity shares. As a result, these companies have control over SOE management (China Daily, January 4, 2000, p. 7). One example is the Renminbi 30 billion debt-for-equity swap of 13 large petrochemical SOEs. Their average debt ratio was brought down from $76.25 \%$ to $47.9 \%$ and many of them turned from losses to gains (People's Daily, April 6, 2000, p. 2). The government can thus provide necessary political backing to the SOEs. Tian (1999) has a model, supported by his cross-sectional results, suggesting that the government provides corporate governance and controls agency cost if it holds a sufficiently large share stake (more than $30 \%$ in his study). In any case, the impact of state ownership on SIP firms is an empirical issue.

\subsection{Legal person shares}

Legal-person shares are owned by domestic institutions, most of which are partially owned by the central or local government. There can be several legal-person shareholders in a listed firm. Legal persons are typically business agencies or enterprises of local governments that helped in starting up the public company either 
by giving permission to operate or by allowing resources under their control to be used for the start up. Legal-person and state shares are similar, not only because many legal persons are actually controlled by the state but also because both legalperson and state shares are not tradable. Although legal-person shares are not tradable, they are transferable to domestic institutions upon approval from the CSRC. As mentioned before, the Chinese government is planning to sell off some of the state-owned shares to private investors in the A-share market. The format for liquidation of state shares is still under discussion. Therefore, legal persons have more common interests with the state rather than with other minority shareholders (see Chen, 1998; Hu and Goergen, 2001). Yet, there can be subtle differences. Che and Qian (1998) develop a theory that in an environment without secure property rights against state encroachment, private ownership leads to excessive revenue hiding. State ownership fails to provide incentives for managers, but local government ownership limits state predation and reduces costly revenue hiding. Indeed, Jin and Qian (1998) find that there are relatively more township-village enterprises (owned by local governments) in provinces where the central government's influence is greater. Hence, local government can play a positive role for a firm. Given that central and local governments can have vastly different impact on firms, legal-persons can also play a different role from the state in SIP firms.

Second, the state is usually represented by a provincial branch of the state asset management bureau, which represents the state in many other companies, too. This significantly reduces the state government's monitoring ability. A legal person, on the other hand, can be more effective in monitoring as it is typically a large blockholder in only one or a few companies. Xu and Wang (1997) argue that legal persons, like institutional investors in the market economies, are active in monitoring managers and enhance the firm's performance. Their findings show that legal-person ownership has a positive impact on the firm, while state ownership has no impact. Qi et al. (2000) also argue that representatives of legal persons have incentives and expertise to monitor and control actions taken by managers. Legal persons can nominate board members, who in turn appoint corporate officials independently. Consequently, the board members are elected from different institutions, have diverse professional backgrounds, and could act to promote the best interest of the legal persons they represent. Their study on Shanghai-listed firms also shows that legal-person ownership has a positive impact on the firm where state ownership has a negative impact.

Third, unlike state ownership, many legal persons have close business connections to the SIP firms. Many legal persons are the SOEs from which the SIP firms were carved out, and some have come about through a debt-equity swap. As part of the restructuring policy on the SOE debt problem, the government allows SOEs to settle debts among themselves by swapping debts for company shares (Ma and Liu, 2000, p. 108). It is conceivable that legal persons have incentives to ensure the profitability of an SOE, as they will benefit directly from good firm performance and suffer from poor firm performance. It is beneficial to them if the SOE is performing valueincreasing activities. 
Yet, it is also possible that legal persons create conflicts of interest within the firm and collude with managers to benefit themselves at the expense of other shareholders. Chen (1998) has found that state ownership has a positive, while legal-person ownership has a negative, impact on a firm. On average, legal persons hold about $32 \%$ of the shares in a SIP firm, some hold more than $60 \%$, and the maximum holding is $90 \%$ (see Appendix A, Panel A). As shown in the appendix of Qi et al. (2000), FAW Jinbei Automotive had 28.8\% A shares, 7.6\% state shares, and $63.6 \%$ legal-person shares in 1996. The two legal persons were China First Automotive Work Group (holding 51\%) and Shenyang Auto Investment (holding $12.6 \%$ ) shares.

\subsection{Other minority shares}

Employee shares are offered to workers and managers of a listed company, usually at a substantial discount. However, employee shares are limited in quantity. In addition, not all companies issue employee shares. After a holding period of six to 12 months, the company can file with the CSRC to allow its employees to sell their shares on the open market. Once sold on the market, they become A shares. On average, employee shares account for less than $2 \%$ of the total shares and act purely as an incentive scheme rather than providing ownership control of any kind.

A shares are similar to ordinary equity shares except that they are exclusively available to Chinese citizens and domestic institutions. They are mostly held and traded by individuals. It is required that A-shares should account for no less than $25 \%$ of total outstanding shares when a company makes its initial public offering. A-share holdings range from $17 \%$ to $33 \%$. Although the company ordinance stipulates that public offers should not be less than $25 \%$ of total equities, this regulation was not followed in early periods (see endnote 9 of Mok, 1995). Also for firms that issue both A and B shares, A shares account for less than $25 \%$. Yet, A-share investors can hardly be major shareholders as for most listed companies. The top ten shareholders are normally the state and legal persons. Even if some individual A shareholders are among the top ten, their holdings are below $0.5 \%$, much smaller than those of state and legal persons. Furthermore, as pointed out by Lin (2000), although CEOs are elected at the shareholders' meeting, the process in practice involves the controlling shareholder (typically the state) appointing the board chairman and CEO. Other board members are appointed by other major shareholders but discussed beforehand with the controlling shareholder. Also, major strategic decisions are agreed outside the formal shareholders' meeting or the boardroom. As a result, A shareholders can hardly select the supervisory board that can be effective in representing their interests.

To attract foreign investors, some SOEs also issue foreign shares. B shares are issued and traded in the two Chinese stock exchanges. Since the Chinese currency is not convertible under the capital account, B shares are quoted and traded in either US dollars on the SHSE or Hong Kong dollars on the SZSE. B shares can only be subscribed for, owned by, and traded amongst foreigners and people from Hong Kong, Macao, and Taiwan. About one-eighth of the listed firms that can meet the 
more stringent requirements have issued B shares. Since June 2001, the B-share market has opened up to Chinese local investors who have foreign currency accounts in the brokerage firms. As the information came out in March, the SHSE B-share market index and the SZSE B-share market index have risen, respectively, two- and three-fold since then. $\mathrm{H}$ shares are issued on the Hong Kong Stock Exchange, and currently there are 50 of them. On average, foreign shares account for less than $2.5 \%$ of the total shares of all companies but for those firms that have actually issued foreign shares, the average is about $35 \%$. In addition, there are not many foreign share blockholders. Therefore, foreign investors, like local investors, are too insignificant to influence a firm's management. As a result, trading is traditionally light in the B-share market, and both B-share and $\mathrm{H}$-share prices are deeply discounted relative to their A-share counterparts (Bailey, 1994; Sun and Tong, 2000).

\section{Results on SOE performance}

We first follow existing studies such as Megginson et al. (1994), Boubakri and Cosset (1998), Dewenter and Malatesta (2001), D'Souza and Megginson (1999), and D'Souza et al. (2000) and compare performance changes three years before and three years after privatization. We use similar testing proxies and methodologies to examine profitability changes, output changes, leverage changes, and employee and productivity changes. Previous studies also looked at the dividend payout. We do not examine this variable due to the data limitations. Dividend data are not available for the years before listing. The prospectus provides up to three years of a firm's financial information before the IPO. Data after the IPO are from the Taiwan Economic Journal (TEJ) database, the China Stock Market and Accounting Research Database (CSMAR) prepared by the China Accounting and Finance Research Center of the Hong Kong Polytechnic University and the Shenzhen GTA Information Technology Company limited and supplemented by the various issues of Shenzhen Stock Exchange Fact Book, Shanghai Stock Exchange Statistics Annual, and the annual financial reports of individual companies.

As at the end of 1998, there are a total of 851 listed firms in China, but we exclude those privatised before 1994. This is because China changed accounting practices in 1993 in a way that reduced the comparability of the data. China's new accounting standards, which are closer to international norms were promoted in July 1993 but took effect in January 1994. The pre-listing data were recompiled by the auditing firms using new standards. We also exclude financial firms, as their financial data are not comparable to other firms, and those firms lacking most of the data we need. Our sample ends up with 634 SOEs that have relatively complete set of data for the following analyses.

\subsection{Profitability change}

One special feature of SOE privatization in China is that SIP firms typically go through primary offerings instead of secondary offerings, which is the norm in 
almost all other countries. This is unlike secondary offerings in which the government sells existing equities and receives all of the sales proceeds and the only effect on the privatized firms comes from ownership change. Under primary offerings, the capital raised through SIP is a capital-raising event for the firm. SIPs thus increase a firm's asset and equity accounts by an equal amount as well as changing the firm's ownership structure somewhat. Furthermore, according to $\mathrm{Yu}$ and Ying (2001), China's regulatory rules allow listed companies to have rights issue up to $30 \%$ of outstanding stocks annually after their listing. Many firms take advantage of this rule to raise additional equity capital even if they have no investment opportunities. Total equity and total asset would also increase dramatically in such cases, which poses a major problem in measuring post-SIP profitability changes. The two common profitability measures, return on assets (ROA) and return on equity (ROE), hence cannot be used as they will decrease mechanically after the share issue even if net income remains constant.

In view of all these, we decide to measure profitability change in two ways. First, we look at the absolute change in real net profit of the SIP firms from before privatization to after privatization. Specifically, we calculate the real net profit by adjusting a firm's annual net income with the annual inflation rate. The value is then normalized to one in the year the firm privatized. If the normalized real net profit after privatization is higher than that before privatization, there is evidence of profitability improvement. The second way is to look at the return on sales (ROS), which is the ratio of net income to sales. Although the real net profit measure and ROS measure can avoid the problem of mechanical increase in equity through primary issue, they cannot avoid the problem of net profits change through having the proceeds invested in marketable securities. We thank the referee for pointing this out to us but there seems no perfect way to clean up the "contamination." Dewenter and Malatesta (2001) find that the results regarding privatization's impact are significantly different between using operating income (i.e. earnings before interest and tax, EBIT) and net income, so we also use real EBIT (REBIT) and EBIT over sales (EBITS) as additional proxies for profitability. EBIT is computed by adding financial charges to EBT, as TEJ database does not provide the EBIT figure.

Yearly empirical proxies for every firm are computed for a seven-year period, three years before through three years after privatization. The mean and median of each proxy are computed across firms over the pre- and post-privatization periods. Year 0 is excluded from the mean calculations as it includes both the public and private ownership phases of the enterprise. The two-tailed Wilcoxon rank-sum test is employed to test for any significant difference in the median changes in the proxy for the pre- and post-privatization periods. Conclusions are made based on the Wilcoxon $Z$ statistic. The statistic is approximately normally distributed for sample size larger than 25 (Kazmier and Pohl, 1984).

The upper panel of Table 1 presents the results on real net profit (RNP). The first row shows the contrasts of the three-year averages of the RNP of SOEs before and after privatization. The median (mean) RNP jumps from $0.72(0.89)$ before privatization to 1.09 (1.03) after privatization. The Wilcoxon test on the median change is 9.80 , which is significant at the $5 \%$ level. The last column shows the 
Table 1

Comparison of absolute earnings before and after privatization

The table presents, in various samples, the number of observations, the mean and median values of real net profit (RNP) and real EBIT (REBIT) for the average of three years pre- and post-privatisation periods, the mean and median change in RNP and REBIT value (post-pre), and the tests of significance of the median change. The Wilcoxon $Z$-test is employed to test for any significant change in the median value (paired observation), and for any significant difference in changes between any two groups. The last column shows the number of positive versus negative changes and the proportion $Z$-test on if the proportion of positive change is greater than $50 \%$.

\begin{tabular}{|c|c|c|c|c|c|c|c|c|}
\hline \multirow[t]{2}{*}{ Variable } & \multirow[t]{2}{*}{ Sample } & \multirow[t]{2}{*}{ Obs. } & \multirow{2}{*}{$\begin{array}{l}\text { Median } \\
\text { (mean) } \\
\text { before }\end{array}$} & \multirow{2}{*}{$\begin{array}{l}\text { Median } \\
\text { (mean) } \\
\text { after }\end{array}$} & \multirow{2}{*}{$\begin{array}{l}\text { Median } \\
\text { (mean) } \\
\text { change }\end{array}$} & \multicolumn{2}{|c|}{ Wilcoxon test } & \multirow{2}{*}{$\begin{array}{l}+\mathrm{ve} /-\mathrm{ve} \\
\text { Ratio }\end{array}$} \\
\hline & & & & & & Paired obs. & Bet. gps. & \\
\hline \multirow[t]{11}{*}{ RNP } & $\begin{array}{l}\text { Whole sample } \\
(-3 \text { to }+3)\end{array}$ & 634 & $\begin{array}{l}0.7277 \\
(0.8967)\end{array}$ & $\begin{array}{l}1.0925 \\
(1.0379)\end{array}$ & $\begin{array}{l}0.3648 \\
(0.1412)\end{array}$ & $9.8020^{* * *}$ & & $\begin{array}{l}433 / 201 \\
(13.5128)^{\text {*** }}\end{array}$ \\
\hline & $\begin{array}{l}\text { SHSE } \\
\text { vs }\end{array}$ & 314 & $\begin{array}{l}0.7060 \\
(0.8559)\end{array}$ & $\begin{array}{l}1.1046 \\
(0.8954)\end{array}$ & $\begin{array}{l}0.3986 \\
(0.0395)\end{array}$ & $7.8635^{* * *}$ & 1.3581 & $\begin{array}{l}221 / 93 \\
(11.1175)^{\text {*** }}\end{array}$ \\
\hline & SZSE & 320 & $\begin{array}{l}0.7426 \\
(0.9368)\end{array}$ & $\begin{array}{l}1.0882 \\
(1.1778)\end{array}$ & $\begin{array}{l}0.3456 \\
(0.2410)\end{array}$ & $5.9888^{* *}$ & & $\begin{array}{l}212 / 108 \\
(8.1327)^{* *}\end{array}$ \\
\hline & $\begin{array}{l}\text { Reg. ind. } \\
\text { vs }\end{array}$ & 58 & $\begin{array}{l}0.7246 \\
(0.7125)\end{array}$ & $\begin{array}{l}1.1972 \\
(1.3591)\end{array}$ & $\begin{array}{l}0.4726 \\
(0.6466)\end{array}$ & $4.8894 * *$ & $2.1379^{* *}$ & $\begin{array}{l}46 / 12 \\
(8.6652)^{* *}\end{array}$ \\
\hline & non-reg. ind. & 576 & $\begin{array}{l}0.7292 \\
(0.9153)\end{array}$ & $\begin{array}{l}1.0797 \\
(1.0056)\end{array}$ & $\begin{array}{l}0.3505 \\
(0.0903)\end{array}$ & $8.7260^{* * *}$ & & $\begin{array}{l}387 / 189 \\
(11.7951)^{\text {*** }}\end{array}$ \\
\hline & $\begin{array}{c}\text { Rev. privatization } \\
\text { vs }\end{array}$ & 158 & $\begin{array}{l}0.7659 \\
(0.9519)\end{array}$ & $\begin{array}{l}1.0009 \\
(0.9700)\end{array}$ & $\begin{array}{l}0.2350 \\
(0.0181)\end{array}$ & $3.2355^{* * *}$ & $2.3156^{* * *}$ & $\begin{array}{l}99 / 59 \\
(4.1091)\end{array}$ \\
\hline & $\begin{array}{c}\text { control } \\
\text { privatization }\end{array}$ & 476 & $\begin{array}{l}0.7198 \\
(0.8784)\end{array}$ & $\begin{array}{l}1.1284 \\
(1.0604)\end{array}$ & $\begin{array}{l}0.4086 \\
(0.1821)\end{array}$ & $9.4227^{* *}$ & & $\begin{array}{l}334 / 142 \\
(13.4825)\end{array}$ \\
\hline & $\begin{array}{c}\text { Foreign share } \\
\text { vs }\end{array}$ & 40 & $\begin{array}{l}0.7569 \\
(0.9849)\end{array}$ & $\begin{array}{l}0.8989 \\
(0.8799)\end{array}$ & $\begin{array}{l}0.1420 \\
(-0.1050)\end{array}$ & 0.1203 & $2.7544 * *$ & $\begin{array}{l}22 / 18 \\
(0.6904)\end{array}$ \\
\hline & no foreign share & 594 & $\begin{array}{l}0.7271 \\
(0.8908)\end{array}$ & $\begin{array}{l}1.1132 \\
(1.0486)\end{array}$ & $\begin{array}{l}0.3861 \\
(0.1578)\end{array}$ & $10.2105^{* * *}$ & & $\begin{array}{l}411 / 183 \\
(14.0078)^{\text {*** }}\end{array}$ \\
\hline & $\begin{array}{l}\text { Firms listed in } \\
\quad 94-95\end{array}$ & 124 & $\begin{array}{l}0.7229 \\
(0.9404)\end{array}$ & $\begin{array}{l}0.8173 \\
(0.5890)\end{array}$ & $\begin{array}{l}0.0944 \\
(-0.3514)\end{array}$ & $8.7260^{* * *}$ & $4.5642^{* * *}$ & $\begin{array}{l}67 / 57 \\
(0.9699)\end{array}$ \\
\hline & $\begin{array}{c}\text { vs } \\
\text { firms listed in } \\
96-98\end{array}$ & 510 & $\begin{array}{l}0.7279 \\
(0.8861)\end{array}$ & $\begin{array}{l}1.1522 \\
(1.1471)\end{array}$ & $\begin{array}{l}0.4243 \\
(0.2610)\end{array}$ & $11.1211^{* *}$ & & $\begin{array}{l}366 / 144 \\
(15.6567)^{\text {*** }}\end{array}$ \\
\hline \multirow[t]{4}{*}{ REBIT } & $\begin{array}{l}\text { Whole sample } \\
(-3 \text { to }+3)\end{array}$ & 606 & $\begin{array}{l}0.8149 \\
(0.9000)\end{array}$ & $\begin{array}{l}1.1386 \\
(1.2722)\end{array}$ & $\begin{array}{l}0.3237 \\
(0.3723)\end{array}$ & $9.1090^{* * *}$ & & $\begin{array}{l}413 / 193 \\
(13.0624)^{\text {*** }}\end{array}$ \\
\hline & $\begin{array}{l}\text { SHSE } \\
\text { vs }\end{array}$ & 293 & $\begin{array}{l}0.8092 \\
(0.8410)\end{array}$ & $\begin{array}{l}1.1554 \\
(1.2372)\end{array}$ & $\begin{array}{l}0.3462 \\
(0.3963)\end{array}$ & $7.3783^{* *}$ & $1.6636^{*}$ & $\begin{array}{l}204 / 89 \\
(10.1541)^{* * *}\end{array}$ \\
\hline & SZSE & 313 & $\begin{array}{l}0.8180 \\
(0.9552)\end{array}$ & $\begin{array}{l}1.0922 \\
(1.3050)\end{array}$ & $\begin{array}{l}0.2742 \\
(0.3498)\end{array}$ & $5.5271^{* * *}$ & & $\begin{array}{l}209 / 104 \\
(8.3999)^{* * *}\end{array}$ \\
\hline & $\begin{array}{l}\text { Reg. ind. } \\
\text { vs }\end{array}$ & 55 & $\begin{array}{l}0.8182 \\
(0.7820)\end{array}$ & $\begin{array}{l}1.2489 \\
(1.4635)\end{array}$ & $\begin{array}{l}0.4307 \\
(0.6815)\end{array}$ & $4.9021^{* *}$ & $2.1791^{* *}$ & $\begin{array}{l}41 / 14 \\
(6.1734)^{* *}\end{array}$ \\
\hline
\end{tabular}


Table 1 (continued)

\begin{tabular}{|c|c|c|c|c|c|c|c|c|}
\hline \multirow[t]{2}{*}{ Variable } & \multirow[t]{2}{*}{ Sample } & \multirow[t]{2}{*}{ Obs. } & \multirow{2}{*}{$\begin{array}{l}\text { Median } \\
\text { (mean) } \\
\text { before }\end{array}$} & \multirow{2}{*}{$\begin{array}{l}\text { Median } \\
\text { (mean) } \\
\text { after }\end{array}$} & \multirow{2}{*}{$\begin{array}{l}\text { Median } \\
\text { (mean) } \\
\text { change }\end{array}$} & \multicolumn{2}{|c|}{ Wilcoxon test } & \multirow{2}{*}{$\begin{array}{l}+\mathrm{ve} /-\mathrm{ve} \\
\text { Ratio }\end{array}$} \\
\hline & & & & & & Paired obs. & Bet. gps. & \\
\hline & non-reg.ind. & 551 & $\begin{array}{l}0.8145 \\
(0.9117)\end{array}$ & $\begin{array}{l}1.1161 \\
(1.2532)\end{array}$ & $\begin{array}{l}0.2616 \\
(0.3414)\end{array}$ & $8.0012^{* *}$ & & $\begin{array}{l}372 / 179 \\
(11.8422)^{* *}\end{array}$ \\
\hline & $\begin{array}{c}\text { Rev. privatization } \\
\text { vs }\end{array}$ & 148 & $\begin{array}{l}0.8825 \\
(1.0627)\end{array}$ & $\begin{array}{l}1.0114 \\
(1.3279)\end{array}$ & $\begin{array}{l}0.1289 \\
(0.2652)\end{array}$ & $2.2389^{* * *}$ & $2.2847^{* * *}$ & $\begin{array}{l}91 / 57 \\
(3.5193)\end{array}$ \\
\hline & $\begin{array}{c}\text { control } \\
\text { privatization }\end{array}$ & 458 & $\begin{array}{l}0.8000 \\
(0.8474)\end{array}$ & $\begin{array}{l}1.1540 \\
(1.2543)\end{array}$ & $\begin{array}{l}0.3540 \\
(0.4069)\end{array}$ & $9.1649^{* *}$ & & $\begin{array}{l}342 / 136 \\
(13.3587)^{* * *}\end{array}$ \\
\hline & $\begin{array}{c}\text { Foreign share } \\
\text { Vs }\end{array}$ & 36 & $\begin{array}{l}0.8618 \\
(0.9400)\end{array}$ & $\begin{array}{l}0.8653 \\
(1.0089)\end{array}$ & $\begin{array}{l}0.0035 \\
(0.0689)\end{array}$ & 0.0056 & $2.0234^{* *}$ & $\begin{array}{l}18 / 18 \\
(0)\end{array}$ \\
\hline & no foreign share & 570 & $\begin{array}{l}0.8114 \\
(0.8974)\end{array}$ & $\begin{array}{l}1.1476 \\
(1.2889)\end{array}$ & $\begin{array}{l}0.3362 \\
(0.3914)\end{array}$ & $0.3590^{* * *}$ & & $\begin{array}{l}395 / 175 \\
(13.8319)^{* * *}\end{array}$ \\
\hline & $\begin{array}{c}\text { Firms listed in } \\
\text { 94-95 }\end{array}$ & 100 & $\begin{array}{l}0.8798 \\
(0.9800)\end{array}$ & $\begin{array}{l}0.7507 \\
(0.9147)\end{array}$ & $\begin{array}{l}-0.1291 \\
(-0.0653)\end{array}$ & 1.5454 & $21.1262^{* * *}$ & $\begin{array}{l}49 / 51 \\
(-0.1951)\end{array}$ \\
\hline & $\begin{array}{c}\text { vs } \\
\text { firms listed in } \\
96-98\end{array}$ & 506 & $\begin{array}{l}0.7988 \\
(0.8841)\end{array}$ & $\begin{array}{l}1.1786 \\
(1.3429)\end{array}$ & $\begin{array}{l}0.3798 \\
(0.4588)\end{array}$ & $10.8329^{* *}$ & & $\begin{array}{l}364 / 142 \\
(15.7854)^{* * *}\end{array}$ \\
\hline
\end{tabular}

$*(* *)$ Denotes significance at the $10 \%(5 \%)$ level (two-tails).

number of firms having higher RNP after privatization relative to the number of firms having lower RNP after privatization. The ratio is $433 / 201$, which means that 433 firms out of a total of 634 show an increase in RNP and only 201 firms show a decrease. A binomial test value of 13.51 suggests that the ratio is statistically different from one at the $5 \%$ level. This provides the first piece of evidence of SOE performance improvement after privatization.

We perform the above comparisons on various groupings for robustness checks. The two-tailed Wilcoxon rank-sum test is further used to examine if the median changes of these measures before and after privatization across the two subgroups within each grouping are the same. The test statistic is approximately normally distributed (Berenson and Levine, 1998). The first grouping is based on the place of listing. Xu and Wang (1997) obtained results different from those of Chen (1998) due to differences in firm samples. Also, it is said that listing regulations on the SHSE are more rigorous than those on the SZSE. Firms listed on the SHSE may have better performance than those listed on the SZSE. Our results give only weak support to such a conjecture, as shown in the second major row of the table. Although firms listed on the SHSE have higher median RNP improvement (0.39) than those listed on the SZSE (0.34), the low cross-group Wilcoxon value of 1.35 suggests that the RNP improvements of the two groups have no significant difference.

The second grouping is on regulated and nonregulated industries. Regulated industries are typically natural monopolies. Bös (1991) suggests that governments have an incentive to monitor such firms actively under asymmetric information to ensure that management decisions are made in accordance with social welfare objectives. Perotti (1995) has a model showing that governments tend to privatize a 
smaller proportion of such firms. China regulates utilities, energy, telecommunication, and the financial industries. The firms in these industries are subject to more government intervention, face less competition, and enjoy more government support. Our results find that firms in the regulated industry show much higher median RNP improvement (equal to 0.47 ) than firms in the nonregulated industry (equal to 0.35 ) and the difference is statistically significant at the $5 \%$ level (the Wilcoxon value being 2.13).

The third grouping is based on the percentage of government ownership retained after privatization. Revenue privatization refers to government ownership of more than $50 \%$ whereas control privatization refers to government ownership of less than $50 \%$ of a company's shares. D'Souza and Megginson (1999) argue that selling voting control to outside investors is most conducive to efficiency improvements. This is because control by outside shareholders, whose objectives are less aligned with those of the politicians, is superior to control by managers whose interests are closer to those of the politicians. Based on this argument, control privatization would be expected to yield superior performance improvements than revenue privatization. Our results support such assertion. Firms with less than $50 \%$ of their shares retained by the government after privatization have much higher RNP improvement (of 0.40 ) than those with more government holdings after privatization (RNP improvement of 0.23 ). The Wilcoxon test statistic between groups is 2.31 , which is significant at the $5 \%$ level. Another possible reason is that government sells more of highly promising SOEs but our later results (Table 8) do not support this argument.

The next comparison is between firms issuing foreign shares from firms not issuing foreign shares. As argued by Boycko et al. (1996), privatization is more effective when both ownership and control are transferred to private hands. If the private hands are foreign, that can be even more effective. So, firms with foreign share issues like $\mathrm{B}, \mathrm{H}$, or $\mathrm{N}$ shares would be expected to yield greater performance improvement than firms without. Surprisingly, our results suggest the opposite. In fact, only firms issuing no foreign shares show significant RNP improvement of 0.38 after privatization. Firms issuing foreign shares show practically no RNP improvement after privatization. This hints on the possibility that foreign ownership control is somehow not effective in ensuring earnings improvement after privatisation. It could also be possible that the government tends to sell bad SOEs to foreign investors. We will investigate this possibility later.

The last comparison contrasts the differences between firms privatized before 1996 from firms privatized in 1996 or later. Since SIP program is completely new to the Chinese government, we are curious if there is a difference in SOEs privatised early from those privatised late. Since there is typically a restructuring process before an SOE goes for SIP, it is conceivable that SOEs privatised early are not as successful as those privatised late due to lack of experience. We group those SOEs privatised in the first two years of our sample IPO period (i.e., 1994 and 1995) as early privatisation and those privatised in the last three years of our sample IPO period (i.e., 1996-1998) as late privatisation. The results confirm that firms privatised earlier perform worse than those privatised later. For SOEs privatised in the years 1994 and 1995, the median RNP increase is 0.09 while those privatised in years 1996 onward, 
the median RNP increase is 0.42 . The cross-group Wilcoxon test value of 4.56 indicates that the difference is statistically significant at the $5 \%$ level.

In the lower panel of Table 1, we compare real earnings before interest and tax (REBIT). The results paint essentially the same picture. That is, the SIP in China shows a significant improvement in REBIT after privatization in general and across various subgroups except for firms with foreign shares and for firms privatised earlier. The REBIT increase for firms with foreign shares is not statistically significant while the REBIT change appears negative for firms privatised early.

However, when we move away from level measure to ratio measure of profitability, the scene switches. Instead of seeing improvements, we observe a general deterioration of profitability after privatization. This holds for the whole sample as well as across various subgroups, as shown in Table 2.

The first row of Table 2 shows the comparisons for the whole sample. The median (mean) ROS changes from $0.12(0.16)$ before privatization to $0.11(0.11)$ after privatization. The Wilcoxon test on the median change is 3.05 , which is statistically significant at the 5\% level. The median (mean) EBIT to sales ratio changes from 0.17 $(0.21)$ to $0.15(0.16)$ with the Wilcoxon test statistics being 3.97 , which is also significant at the $5 \%$ level. As a point of reference, the median (mean) ROA drops from $0.09(0.11)$ before privatization to $0.05(0.05)$ after privatization. The corresponding figures for ROE are $0.22(0.27)$ and $0.10(0.05)$, respectively. That is to say, if profitability is measured in return form, there is evidence of deterioration after privatization. If looking at the numbers in the last column, 279 firms show ROS increase after privatization and 355 show a decrease. The binomial test value of -2.67 indicates that the ratio is statistically different from 1. Similarly, 245 firms show EBITS increase after privatization and 369 show a decrease. The binomial test value is even bigger, equal to -4.07 . More firms show a return decrease than increase after privatization.

Significant decrease in earnings returns hold across almost all subgroups except for SOEs in regulated industries. Furthermore, the extent of return decrease after privatisation is similar across various contrast subgroup pairs by and large. The notable exception is time of privatisation. At the bottom of Table 2, the median ROS change for early privatised SOEs is -0.03 whereas that for later privatised SOEs is -0.01 . The Wilcoxon test between groups gives a value of 1.69 , which is statistically significant at the $10 \%$ level. Similar situation is found for EBITS. That is consistent with the findings in Table 1 that SOEs privatised earlier perform worse than SOEs privatised later.

We observe a general increase in earnings after privatisation in Table 1 but a general decrease in profitability returns now. This hints at the possibility that sales increase at a faster rate than earnings do. That is what seems to be the case when we examine the output changes.

\subsection{Output changes}

Megginson et al. (1994) point out that, with better incentives, more flexible financing opportunities, increased competition, and greater scope for entrepreneurial 
Table 2

Comparison of the percentage profitability of privatised firms

The table presents, in various samples, the number of observations, the mean and median values of return on sales (ROS) and return on RBIT (EBIT/sales) for the average of three years pre- and post-privatisation periods, the mean and median change in ROS and EBIT/sales value (post-pre), and the tests of significance of the median change. The Wilcoxon $Z$-test is employed to test for any significant change in the median value (paired observation), and for any significant difference in changes between any two groups. The last column shows the number of positive versus negative changes and the proportion $Z$-test on if the proportion of positive change is greater than $50 \%$.

\begin{tabular}{|c|c|c|c|c|c|c|c|c|c|}
\hline \multirow{2}{*}{ Sample } & \multirow{2}{*}{ Obs. } & \multirow{2}{*}{ Variable } & \multirow{2}{*}{ Subsample } & \multirow{2}{*}{$\begin{array}{l}\text { Median } \\
\text { (mean) } \\
\text { before }\end{array}$} & \multirow{2}{*}{$\begin{array}{l}\text { Median } \\
\text { (mean) } \\
\text { after }\end{array}$} & \multirow{2}{*}{$\begin{array}{l}\text { Median } \\
\text { (mean) } \\
\text { change }\end{array}$} & \multicolumn{2}{|c|}{ Wilcoxon test } & \multirow{2}{*}{$\begin{array}{l}+\mathrm{ve} /-\mathrm{ve} \\
\text { Ratio }\end{array}$} \\
\hline & & & & & & & $\begin{array}{l}\text { Paired } \\
\text { obs. }\end{array}$ & $\begin{array}{l}\text { Bet. } \\
\text { groups }\end{array}$ & \\
\hline \multirow[t]{2}{*}{$\begin{array}{l}\text { Whole sample } \\
(-3 \text { to }+3)\end{array}$} & 634 & ROS & & $\begin{array}{l}0.1234 \\
(0.1647)\end{array}$ & $\begin{array}{l}0.1142 \\
(0.1136)\end{array}$ & $\begin{array}{l}-0.0092 \\
(-0.0511)\end{array}$ & $3.0547^{* *}$ & & $\begin{array}{l}279 / 355 \\
(-2.6737)^{* *}\end{array}$ \\
\hline & 614 & $\begin{array}{l}\text { EBIT/ } \\
\text { sales }\end{array}$ & & $\begin{array}{l}0.1728 \\
(0.2119)\end{array}$ & $\begin{array}{l}0.1550 \\
(0.1636)\end{array}$ & $\begin{array}{l}-0.0178 \\
(-0.0482)\end{array}$ & $3.9729 * *$ & & $\begin{array}{l}245 / 369 \\
(-4.0743)^{\text {*** }}\end{array}$ \\
\hline \multirow[t]{4}{*}{ SHSE vs SZSE } & 314 & ROS & SH & $\begin{array}{l}0.1139 \\
(0.1650)\end{array}$ & $\begin{array}{l}0.1149 \\
(0.1075)\end{array}$ & $\begin{array}{l}0.001 \\
(-0.0575)\end{array}$ & 1.6366 & 0.1360 & $\begin{array}{l}137 / 177 \\
(-1.9828)^{* * *}\end{array}$ \\
\hline & 320 & & $\mathrm{SZ}$ & $\begin{array}{l}0.1293 \\
(0.1645)\end{array}$ & $\begin{array}{l}0.1132 \\
(0.1196)\end{array}$ & $\begin{array}{l}-0.0161 \\
(-0.0449)\end{array}$ & $2.6649 * *$ & & $\begin{array}{l}142 / 178 \\
(-1.7947)^{*}\end{array}$ \\
\hline & 299 & $\begin{array}{l}\text { EBIT/ } \\
\text { sales }\end{array}$ & $\mathrm{SH}$ & $\begin{array}{l}0.1641 \\
(0.2080)\end{array}$ & $\begin{array}{l}0.1543 \\
(0.1575)\end{array}$ & $\begin{array}{l}-0.0098 \\
(-0.0505)\end{array}$ & $2.4668^{* *}$ & 0.7455 & $\begin{array}{l}128 / 171 \\
(-2.1479)^{* * *}\end{array}$ \\
\hline & 315 & & $\mathrm{SZ}$ & $\begin{array}{l}0.1851 \\
(0.2155)\end{array}$ & $\begin{array}{l}0.1560 \\
(0.1694)\end{array}$ & $\begin{array}{l}-0.0291 \\
(-0.0461)\end{array}$ & $3.1398^{* *}$ & & $\begin{array}{l}117 / 198 \\
(-3.5027)^{* *}\end{array}$ \\
\hline $\begin{array}{l}\text { Regulated } \\
\text { industry }\end{array}$ & 58 & ROS & Regulated & $\begin{array}{l}0.1677 \\
(0.2059)\end{array}$ & $\begin{array}{l}0.1919 \\
(0.1700)\end{array}$ & $\begin{array}{l}0.0242 \\
(-0.0359)\end{array}$ & 0.2954 & 0.9285 & $\begin{array}{l}30 / 28 \\
(0.2695)\end{array}$ \\
\hline vs & 576 & & $\begin{array}{l}\text { Non- } \\
\text { regulated }\end{array}$ & $\begin{array}{l}0.1180 \\
(0.1606)\end{array}$ & $\begin{array}{l}0.1097 \\
(0.1079)\end{array}$ & $\begin{array}{l}-0.0083 \\
(-0.0527)\end{array}$ & $3.0739 * *$ & & $\begin{array}{l}249 / 327 \\
(-2.8336)^{* *}\end{array}$ \\
\hline \multirow[t]{2}{*}{$\begin{array}{l}\text { non-regulated } \\
\text { industry }\end{array}$} & 55 & $\begin{array}{l}\text { EBIT/ } \\
\text { sales }\end{array}$ & Regulated & $\begin{array}{l}0.2265 \\
(0.2579)\end{array}$ & $\begin{array}{l}0.2558 \\
(0.2357)\end{array}$ & $\begin{array}{l}0.0293 \\
(-0.0221)\end{array}$ & 0.2630 & 1.2643 & $\begin{array}{l}25 / 30 \\
(-0.6099)\end{array}$ \\
\hline & 559 & & $\begin{array}{l}\text { Non- } \\
\text { regulated }\end{array}$ & $\begin{array}{l}0.1680 \\
(0.2073)\end{array}$ & $\begin{array}{l}0.1515 \\
(0.1565)\end{array}$ & $\begin{array}{l}-0.0165 \\
(-0.0508)\end{array}$ & $4.0050^{* *}$ & & $\begin{array}{l}220 / 339 \\
(-4.051)^{* *}\end{array}$ \\
\hline \multirow{2}{*}{$\begin{array}{l}\text { Revenue } \\
\text { privatisation } \\
\text { vs }\end{array}$} & 158 & ROS & Revenue & $\begin{array}{l}0.1124 \\
(0.1531)\end{array}$ & $\begin{array}{l}0.1052 \\
(0.1066)\end{array}$ & $\begin{array}{l}-0.0072 \\
(-0.0465)\end{array}$ & $2.0940^{* *}$ & 1.0304 & $\begin{array}{l}60 / 98 \\
(-2.358)^{* *}\end{array}$ \\
\hline & 476 & & Control & $\begin{array}{l}0.1240 \\
(0.1686)\end{array}$ & $\begin{array}{l}0.1182 \\
(0.1159)\end{array}$ & $\begin{array}{l}-0.0058 \\
(-0.0527)\end{array}$ & $2.3033^{* *}$ & & $\begin{array}{l}219 / 257 \\
(-1.6061)\end{array}$ \\
\hline \multirow[t]{2}{*}{$\begin{array}{l}\text { control } \\
\text { privatisation }\end{array}$} & 152 & $\begin{array}{l}\text { EBIT/ } \\
\text { sales }\end{array}$ & Revenue & $\begin{array}{l}0.1700 \\
(0.2087)\end{array}$ & $\begin{array}{l}0.1495 \\
(0.1529)\end{array}$ & $\begin{array}{l}-0.0205 \\
(-0.0558)\end{array}$ & $2.7711^{* *}$ & $0.1703^{*}$ & $\begin{array}{l}54 / 98 \\
(-2.6405)^{* *}\end{array}$ \\
\hline & 462 & & Control & $\begin{array}{l}0.1736 \\
(0.2129)\end{array}$ & $\begin{array}{l}0.1582 \\
(0.1671)\end{array}$ & $\begin{array}{l}-0.0154 \\
(-0.0457)\end{array}$ & $2.9736^{* *}$ & & $\begin{array}{l}191 / 271 \\
(-3.1213)^{* *}\end{array}$ \\
\hline $\begin{array}{l}\text { With } \\
\text { foreign share }\end{array}$ & 40 & ROS & Foreign & $\begin{array}{l}0.1087 \\
(0.1558)\end{array}$ & $\begin{array}{l}0.0846 \\
(0.0571)\end{array}$ & $\begin{array}{l}-0.0241 \\
(-0.0987)\end{array}$ & $1.9197^{*}$ & $1.9910^{*}$ & $\begin{array}{l}9 / 31 \\
(-1.8507)^{*}\end{array}$ \\
\hline
\end{tabular}


Table 2 (continued)

\begin{tabular}{|c|c|c|c|c|c|c|c|c|c|}
\hline \multirow{2}{*}{ Sample } & \multirow{2}{*}{ Obs. } & \multirow{2}{*}{ Variable } & \multirow{2}{*}{ Subsample } & \multirow{2}{*}{$\begin{array}{l}\text { Median } \\
\text { (mean) } \\
\text { before }\end{array}$} & \multirow{2}{*}{$\begin{array}{l}\text { Median } \\
\text { (mean) } \\
\text { after }\end{array}$} & \multirow{2}{*}{$\begin{array}{l}\text { Median } \\
\text { (mean) } \\
\text { change }\end{array}$} & \multicolumn{2}{|c|}{ Wilcoxon test } & \multirow{2}{*}{$\begin{array}{l}+\mathrm{ve} /-\mathrm{ve} \\
\text { Ratio }\end{array}$} \\
\hline & & & & & & & $\begin{array}{l}\text { Paired } \\
\text { obs. }\end{array}$ & $\begin{array}{l}\text { Bet. } \\
\text { groups }\end{array}$ & \\
\hline vs & 594 & & Local & $\begin{array}{l}0.1245 \\
(0.1653)\end{array}$ & $\begin{array}{l}0.1171 \\
(0.1174)\end{array}$ & $\begin{array}{l}-0.0074 \\
(-0.0479)\end{array}$ & $2.6765^{* * * *}$ & & $\begin{array}{l}270 / 324 \\
(-2.0209)^{* *}\end{array}$ \\
\hline Without & 36 & $\begin{array}{l}\text { EBIT/ } \\
\text { sales }\end{array}$ & Foreign & $\begin{array}{l}0.1533 \\
(0.1950)\end{array}$ & $\begin{array}{l}0.1061 \\
(0.0985)\end{array}$ & $\begin{array}{l}-0.0472 \\
(-0.0965)\end{array}$ & $1.8526^{*}$ & 1.2109 & $\begin{array}{l}11 / 25 \\
(-1.5261)\end{array}$ \\
\hline foreign share & 578 & & Local & $\begin{array}{l}0.1756 \\
(0.2129)\end{array}$ & $\begin{array}{l}0.1558 \\
(0.1677)\end{array}$ & $\begin{array}{l}-0.0198 \\
(-0.0452)\end{array}$ & $3.6296^{* *}$ & & $\begin{array}{l}234 / 344 \\
(-3.7703)^{* *}\end{array}$ \\
\hline $\begin{array}{l}\text { Firms listed in } \\
94-95\end{array}$ & 124 & ROS & 94,95 & $\begin{array}{l}0.0994 \\
(0.1309)\end{array}$ & $\begin{array}{l}0.0681 \\
(0.0771)\end{array}$ & $\begin{array}{l}-0.0313 \\
(-0.0537)\end{array}$ & $2.7772^{* *}$ & $1.6965^{*}$ & $\begin{array}{l}47 / 77 \\
(-2.0963)^{\text {** }}\end{array}$ \\
\hline vs & 510 & & $96,97,98$ & $\begin{array}{l}0.1290 \\
(0.1730)\end{array}$ & $\begin{array}{l}0.1214 \\
(0.1225)\end{array}$ & $\begin{array}{l}-0.0076 \\
(-0.0505)\end{array}$ & $2.0232^{* *}$ & & $\begin{array}{l}232 / 278 \\
(-1.859)^{*}\end{array}$ \\
\hline \multirow[t]{2}{*}{$\begin{array}{l}\text { Firms listed in } \\
96-98\end{array}$} & 107 & \multirow[t]{2}{*}{$\begin{array}{l}\text { EBIT/ } \\
\text { sales }\end{array}$} & 94,95 & $\begin{array}{l}0.1475 \\
(0.1796)\end{array}$ & $\begin{array}{l}0.1026 \\
(0.1184)\end{array}$ & $\begin{array}{l}-0.0449 \\
(-0.0612)\end{array}$ & $2.8218^{* *}$ & $1.8394^{*}$ & $\begin{array}{l}35 / 72 \\
(-2.4822)^{* *}\end{array}$ \\
\hline & 507 & & $96,97,98$ & $\begin{array}{l}0.1834 \\
(0.2187)\end{array}$ & $\begin{array}{l}0.1644 \\
(0.1732)\end{array}$ & $\begin{array}{l}-0.0190 \\
(-0.0455)\end{array}$ & $3.0666^{* *}$ & & $\begin{array}{l}210 / 297 \\
(-3.2458)^{* *}\end{array}$ \\
\hline
\end{tabular}

$*(* *)$ Denotes significance at the $10 \%(5 \%)$ level (two-tails).

initiative, governments hope and expect that real sales will increase after privatization. On the other hand, Boycko et al. (1996) argue that effective privatization will lead to a reduction in output, since the government can no longer entice managers through subsidies to maintain inefficiently high output levels. Thus, output levels could go either way after privatization. The proxy variable used is real sales, which is normalized to one in the year of privatization (Year 0).

The real sales for the whole sample with a seven-year window increase from a median (mean) of $0.88(0.91)$ before privatization to 1.24 (1.45) after privatization, giving an increase of $0.36(0.53)$. The Wilcoxon statistic is a highly significant 15.71 . As a result, it is not surprisingly to see that three-quarters of the sample firms experiences an increase in real sales, resulting in a highly significant binomial statistic of 21.82. The results are robust across various groupings of the sample firms. Beware that some or the entire rise may be the result of price increases rather than increased unit sales. In that case, the increase would reduce social welfare rather than increase it. We thank the referee for pointing out this. The increase is especially significant for firms under control privatization (the fourth major row), for firms without foreign ownership (the second last row), and for firms privatised in later years (the bottom row). Recall that these subgroups also show significantly higher earnings increases than their corresponding counterparts. As a result, these subgroups exhibit less profitability return drop after privatisation than their correspondent subgroup counterparts. This conforms to our conjecture that the return decreases in ROS and EBITS are due to the increase in output faster than the increase in earnings after privatization. Anyway, output does increase after privatization and is consistent with 
results of Megginson et al. (1994), Boubakri and Cosset (1998), and D'Souza and Megginson (1999).

\subsection{Leverage}

SOEs are expected to have high leverage due to three reasons. The cost of borrowing is lower as the SOEs carry (implicit or explicit) government guarantees. Also, borrowing is the only avenue to raise funds (apart from the government's equity injections) since SOEs do not have access to private investors and chronicle low profitability or even loss makes retained earnings hardly a viable funding source. Hence, after privatization, the leverage of former SOEs would be expected to drop as the state's withdrawal of debt guarantees would increase their cost of borrowing, and also, the former SOEs would now have access to public equity markets. Most studies find leverage decline of SOE after privatization (Megginson et al., 1994). However, since the state government set an annual national quota of IPOs up until 1999, provincial governments typically allocate the quota to as many firms as possible, preventing individual SOEs from raising as much equity capital as needed. Bank loans are still an important and essential source of capital. Furthermore, since SIP proceeds go to the privatised firms, the borrowing power of the firms is enhanced. The capital structure theories also suggest that the benefit of interest tax shield encourages higher leverage that could lead to higher firm value and higher return on equity so long as the possible bankruptcy costs are factored in. Hence, there are opposing forces on leverage position of these privatised SOEs (Table 3).

The typical measures of leverage are the long-term-debt-to-equity ratio (LLE) and the total debt-to-asset ratio (LA). However, these two measures face the same problem that plagues the use of ROA and ROE as measures for profitability we discussed before. That is, primary SIP leads to higher total equities and total assets of the SOEs after privatization, which, in turn, lower LLE and LA mechanically. To mitigate the problem, we take an income view of debt and adopt two less popular but still common measures of leverage, the operating cash flow to total debt (OCF/TD) and the times interest earned (TIE). OCF/TD indicates "a firm's ability to cover total debt with the yearly cash flow" (Gibson, 1995, p. 498). TIE, the ratio of EBIT to interest expense, indicates "a long-term debt-paying ability from the income statement view" (Gibson, 1995, p. 311). Notice that just opposite to the interpretation of LLE and LA, the higher the OCF/TD and TIE ratios, the better the firm's leverage condition. Table 4 presents the comparison results.

The whole sample in aggregate shows that OCF/TD drops after the government's divestiture from a median (mean) of $0.23(0.35)$ before privatization to $0.18(0.23)$ after privatisation. Although there are no reasonable figures for the $\mathrm{OCF} / \mathrm{TD}$ ratio, the median values here seem to be quite low as 0.4 and 0.5 are not uncommon figures in US firms. As will be seen shortly, a median TIE value is found to be 6 times, which is also considered to be low. These figures suggest that SOEs in China are indeed highly levered. A Wilcoxon value of 5.35 suggests that the drop is statistically significant at all conventional confidence level. Furthermore, only 94 firms show leverage improvement after privatisation, contrasting with 194 firms having leverage 
Table 3

Results for the output (real sales) of privatised firms

The table presents, in various samples, the number of observations, the mean and median values of real sales for the average of three years pre- and post-privatisation periods, the mean and median change in real sales value (post-pre), and the tests of significance of the median change. The real sales is standardized to one in year 0 (the year of privatization). The Wilcoxon $Z$-test is employed to test for any significant change in the median value (paired observation), and for any significant difference in changes between any two groups. The last column shows the number of positive versus negative changes and the proportion $Z$-test on if the proportion of positive change is greater than $50 \%$.

\begin{tabular}{|c|c|c|c|c|c|c|c|c|c|}
\hline \multirow{2}{*}{ Sample } & \multirow{2}{*}{ Obs. } & \multirow{2}{*}{ Variable } & \multirow{2}{*}{ Subsample } & \multirow{2}{*}{$\begin{array}{l}\text { Median } \\
\text { (mean) } \\
\text { before }\end{array}$} & \multirow{2}{*}{$\begin{array}{l}\text { Median } \\
\text { (mean) } \\
\text { after }\end{array}$} & \multirow{2}{*}{$\begin{array}{l}\text { Median } \\
\text { (mean) } \\
\text { change }\end{array}$} & \multicolumn{2}{|c|}{ Wilcoxon test } & \multirow{2}{*}{$\begin{array}{l}+ \text { ve/-ve } \\
\text { Ratio }\end{array}$} \\
\hline & & & & & & & $\begin{array}{l}\text { Paired } \\
\text { obs. }\end{array}$ & $\begin{array}{l}\text { Bet. } \\
\text { groups }\end{array}$ & \\
\hline $\begin{array}{l}\text { Whole sample } \\
(-3 \text { to }+3)\end{array}$ & 633 & $\begin{array}{l}\text { Real } \\
\text { sales }\end{array}$ & & $\begin{array}{l}0.8827 \\
(0.9168)\end{array}$ & $\begin{array}{l}1.2489 \\
(1.4516)\end{array}$ & $\begin{array}{l}0.3662 \\
(0.5348)\end{array}$ & $15.7160^{* *}$ & & $\begin{array}{l}475 / 158 \\
(21.8289)^{* *}\end{array}$ \\
\hline $\begin{array}{l}\text { SHSE } \\
\text { vs }\end{array}$ & 314 & $\begin{array}{l}\text { Real } \\
\text { sales }\end{array}$ & SH & $\begin{array}{l}0.8829 \\
(0.9048)\end{array}$ & $\begin{array}{l}1.2413 \\
(1.4903)\end{array}$ & $\begin{array}{l}0.3584 \\
(0.5855)\end{array}$ & $11.4006^{* *}$ & 0.8457 & $\begin{array}{l}236 / 78 \\
(15.4849)^{* * *}\end{array}$ \\
\hline SZSE & 319 & & $\mathrm{SZ}$ & $\begin{array}{l}0.8827 \\
(0.9285)\end{array}$ & $\begin{array}{l}1.2501 \\
(1.4134)\end{array}$ & $\begin{array}{l}0.3674 \\
(0.4848)\end{array}$ & $10.7671^{* * *}$ & & $\begin{array}{l}239 / 80 \\
(15.3629)^{\text {** }}\end{array}$ \\
\hline $\begin{array}{l}\text { Regulated } \\
\text { industry }\end{array}$ & 58 & $\begin{array}{l}\text { Real } \\
\text { sales }\end{array}$ & Regulated & $\begin{array}{l}0.8870 \\
(0.9299)\end{array}$ & $\begin{array}{l}1.4218 \\
(1.7043)\end{array}$ & $\begin{array}{l}0.5348 \\
(0.7744)\end{array}$ & $5.7232^{* *}$ & 1.5741 & $\begin{array}{l}45 / 13 \\
(7.7499)^{* *}\end{array}$ \\
\hline $\begin{array}{l}\text { Non-regulated } \\
\text { industry }\end{array}$ & 575 & & $\begin{array}{l}\text { Non- } \\
\text { regulated }\end{array}$ & $\begin{array}{l}0.8827 \\
(0.9155)\end{array}$ & $\begin{array}{l}1.2260 \\
(1.4261)\end{array}$ & $\begin{array}{l}0.3433 \\
(0.5106)\end{array}$ & $14.6547^{* *}$ & & $\begin{array}{l}430 / 145 \\
(20.4495)^{\text {*** }}\end{array}$ \\
\hline $\begin{array}{l}\text { Revenue } \\
\text { privatisation } \\
\text { vs }\end{array}$ & 158 & $\begin{array}{l}\text { Real } \\
\text { sales }\end{array}$ & Revenue & $\begin{array}{l}0.9202 \\
(0.9515)\end{array}$ & $\begin{array}{l}1.1502 \\
(1.3396)\end{array}$ & $\begin{array}{l}0.2300 \\
(0.3881)\end{array}$ & $5.7205^{* *}$ & $2.7422 * *$ & $\begin{array}{l}107 / 51 \\
(6.4326)^{* *}\end{array}$ \\
\hline $\begin{array}{l}\text { Control } \\
\text { privatisation }\end{array}$ & 475 & & Control & $\begin{array}{l}0.8732 \\
(0.9052)\end{array}$ & $\begin{array}{l}1.2920 \\
(1.4888)\end{array}$ & $\begin{array}{l}0.4188 \\
(0.5835)\end{array}$ & $14.7816^{* *}$ & & $\begin{array}{l}368 / 107 \\
(22.1854)^{* * *}\end{array}$ \\
\hline $\begin{array}{l}\text { With } \\
\text { foreign share } \\
\text { vs }\end{array}$ & 40 & $\begin{array}{l}\text { Real } \\
\text { sales }\end{array}$ & $\begin{array}{l}\text { With } \\
\text { foreign }\end{array}$ & $\begin{array}{l}0.9077 \\
(0.9355)\end{array}$ & $\begin{array}{l}1.1208 \\
(1.2129)\end{array}$ & $\begin{array}{l}0.2131 \\
(0.2775)\end{array}$ & $2.7761^{* *}$ & $1.7790^{*}$ & $\begin{array}{l}25 / 15 \\
(2.0155)^{* *}\end{array}$ \\
\hline $\begin{array}{l}\text { Without } \\
\text { foreign share }\end{array}$ & 593 & & Local & $\begin{array}{l}0.8813 \\
(0.9155)\end{array}$ & $\begin{array}{l}1.2529 \\
(1.4676)\end{array}$ & $\begin{array}{l}0.3716 \\
(0.5521)\end{array}$ & $15.5341^{* *}$ & & $\begin{array}{l}450 / 143 \\
(22.3452)^{* *}\end{array}$ \\
\hline $\begin{array}{l}\text { Firms listed in } \\
94-95\end{array}$ & 124 & $\begin{array}{l}\text { Real } \\
\text { sales }\end{array}$ & $\begin{array}{l}\text { Early } \\
\text { privatization }\end{array}$ & $\begin{array}{l}0.9405 \\
(0.9885)\end{array}$ & $\begin{array}{l}0.9743 \\
(1.1604)\end{array}$ & $\begin{array}{l}0.0338 \\
(0.1720)\end{array}$ & $1.6969^{*}$ & $6.0865^{* *}$ & $\begin{array}{l}68 / 56 \\
(1.1827)\end{array}$ \\
\hline vs & & & & & & & & & \\
\hline $\begin{array}{l}\text { Firms listed in } \\
96-98\end{array}$ & 509 & & $\begin{array}{l}\text { Late } \\
\text { privatization }\end{array}$ & $\begin{array}{l}0.8730 \\
(0.8993)\end{array}$ & $\begin{array}{l}1.3062 \\
(1.5225)\end{array}$ & $\begin{array}{l}0.4332 \\
(0.6231)\end{array}$ & $16.6443^{* *}$ & & $\begin{array}{l}407 / 102 \\
(26.9781)^{* * *}\end{array}$ \\
\hline
\end{tabular}

$*(* *)$ Denotes significance at the 10\% (5\%) level (two-tails).

deterioration after privatization. Missing data for tax and depreciation to compute for OCF lead to smaller number of observations. The binomial value of -5.89 suggests that deteriorating firms outnumbers improving firms at a statistically significant $5 \%$ level. 
Table 4

Results for the leverage of privatised firms

The table presents, in various samples, the number of observations, the mean and median values of the time-interest-earned (TIE) and cash flow to total debt ratio (OCF/TD) for the average of three years preand post-privatization periods, the mean and median change in the output value (post-pre), and the tests of significance of the median change. The Wilcoxon $Z$-test is employed to test for any significant change'in the median value (paired observation), and for any significant difference in changes between any two groups. The last column shows the number of positive versus negative changes and the proportion $Z$-test on if the proportion of positive change is greater than $50 \%$.

\begin{tabular}{|c|c|c|c|c|c|c|c|c|c|}
\hline \multirow{2}{*}{ Sample } & \multirow{2}{*}{ Variable } & & \multirow{2}{*}{$N$} & \multirow[b]{2}{*}{$\begin{array}{l}\text { Median } \\
\text { (mean) } \\
\text { before }\end{array}$} & \multirow{2}{*}{$\begin{array}{l}\text { Median } \\
\text { (mean) } \\
\text { after }\end{array}$} & \multirow{2}{*}{$\begin{array}{l}\text { Median } \\
\text { (mean) } \\
\text { change }\end{array}$} & \multicolumn{2}{|c|}{ Wilcoxon test } & \multirow{2}{*}{$\begin{array}{l}+\mathrm{ve} /-\mathrm{ve} \\
\text { Ratio } \\
\text { (Prop. Z) }\end{array}$} \\
\hline & & & & & & & $\begin{array}{l}\text { Paired } \\
\text { obs. }\end{array}$ & $\begin{array}{l}\text { Bet. } \\
\text { groups }\end{array}$ & \\
\hline \multirow[t]{2}{*}{$\begin{array}{l}\text { Whole } \\
\text { sample }\end{array}$} & \multicolumn{2}{|l|}{$\mathrm{OCF} / \mathrm{TD}$} & 288 & $\begin{array}{l}0.2360 \\
(0.3521)\end{array}$ & $\begin{array}{l}0.1800 \\
(0.2328)\end{array}$ & $\begin{array}{l}-0.0560 \\
(-0.1193)\end{array}$ & \multicolumn{2}{|l|}{$5.3551^{* *}$} & $\begin{array}{l}94 / 194 \\
(-5.892)^{\text {*** }}\end{array}$ \\
\hline & \multicolumn{2}{|l|}{ TIE } & 612 & $\begin{array}{l}6.2485 \\
(-7.4965)\end{array}$ & $\begin{array}{l}4.7340 \\
(6.0356)\end{array}$ & $\begin{array}{l}-1.5145 \\
(13.5321)\end{array}$ & \multicolumn{2}{|l|}{$4.023^{* *}$} & $\begin{array}{l}278 / 334 \\
(-2.264)^{* * *}\end{array}$ \\
\hline $\begin{array}{l}\text { Firms listed } \\
\text { on SHSE }\end{array}$ & \multirow[t]{2}{*}{$\mathrm{OCF} / \mathrm{TD}$} & SHSE & 167 & $\begin{array}{l}0.2369 \\
(0.3821)\end{array}$ & $\begin{array}{l}0.1787 \\
(0.2394)\end{array}$ & $\begin{array}{l}-0.0582 \\
(-0.1428)\end{array}$ & $3.9768^{* *}$ & 0.3512 & $\begin{array}{l}57 / 110 \\
(-5.385)^{* * *}\end{array}$ \\
\hline \multirow[t]{2}{*}{ vs } & & SZSE & 121 & $\begin{array}{l}0.2297 \\
(0.3108)\end{array}$ & $\begin{array}{l}0.1832 \\
(0.2239)\end{array}$ & $\begin{array}{l}-0.0466 \\
(-0.0869)\end{array}$ & $3.5188^{* *}$ & & $\begin{array}{l}37 / 84 \\
(-6.591)^{* * *}\end{array}$ \\
\hline & \multirow[t]{2}{*}{ TIE } & SHSE & 296 & $\begin{array}{l}5.9421 \\
(-26.7399)\end{array}$ & $\begin{array}{l}4.9054 \\
(2.1315)\end{array}$ & $\begin{array}{l}-1.0366 \\
(28.8714)\end{array}$ & $2.052^{* *}$ & 1.488 & $\begin{array}{l}140 / 156 \\
(-0.930)\end{array}$ \\
\hline $\begin{array}{l}\text { listed } \\
\text { on SZSE }\end{array}$ & & SZSE & 316 & $\begin{array}{l}6.4437 \\
(10.5289)\end{array}$ & $\begin{array}{l}4.5936 \\
(9.6926)\end{array}$ & $\begin{array}{l}-1.8502 \\
(-0.8364)\end{array}$ & $3.817^{* * *}$ & & $\begin{array}{l}138 / 178 \\
(-2.250)^{* * *}\end{array}$ \\
\hline \multirow[t]{2}{*}{$\begin{array}{l}\text { Firms in the } \\
\text { reg. ind }\end{array}$} & \multirow[t]{2}{*}{$\mathrm{OCF} / \mathrm{TD}$} & Reg. & 32 & $\begin{array}{l}0.3065 \\
(0.5130)\end{array}$ & $\begin{array}{l}0.2091 \\
(0.2678)\end{array}$ & $\begin{array}{l}-0.0974 \\
(-0.2452)\end{array}$ & $1.9939^{* *}$ & $1.7595^{*}$ & $\begin{array}{l}8 / 24 \\
(-8.485)^{* *}\end{array}$ \\
\hline & & Non-reg. & 256 & $\begin{array}{l}0.2296 \\
(0.3320)\end{array}$ & $\begin{array}{l}0.1735 \\
(0.2285)\end{array}$ & $\begin{array}{l}-0.0561 \\
(-0.1036)\end{array}$ & $5.0026^{* *}$ & & $\begin{array}{l}86 / 170 \\
(-5.568)^{* * *}\end{array}$ \\
\hline \multirow{2}{*}{$\begin{array}{l}\text { Firms not } \\
\text { in the } \\
\text { reg. ind. }\end{array}$} & \multirow[t]{2}{*}{ TIE } & Reg. & 54 & $\begin{array}{l}6.8290 \\
(-35.7057)\end{array}$ & $\begin{array}{l}5.5150 \\
(-17.6578)\end{array}$ & $\begin{array}{l}-1.3140 \\
(18.0479)\end{array}$ & 0.765 & 0.180 & $\begin{array}{l}138 / 178 \\
(-2.250)^{* *}\end{array}$ \\
\hline & & Non-reg. & 558 & $\begin{array}{l}6.1893 \\
(-4.7666)\end{array}$ & $\begin{array}{l}4.5866 \\
(8.3285)\end{array}$ & $\begin{array}{l}-1.6026 \\
(13.0951)\end{array}$ & $4.161^{* *}$ & & $\begin{array}{l}254 / 304 \\
(-2.117)^{* * *}\end{array}$ \\
\hline \multirow[t]{2}{*}{$\begin{array}{l}\text { Revenue } \\
\text { privatization }\end{array}$} & \multirow[t]{2}{*}{$\mathrm{OCF} / \mathrm{TD}$} & Revenue & 68 & $\begin{array}{l}0.2286 \\
(0.4036)\end{array}$ & $\begin{array}{l}0.2032 \\
(0.2395)\end{array}$ & $\begin{array}{l}-0.0254 \\
(-0.1641)\end{array}$ & $2.5091^{* * *}$ & 0.2941 & $\begin{array}{l}27 / 41 \\
(-3.493)^{* *}\end{array}$ \\
\hline & & Control & 220 & $\begin{array}{l}0.2371 \\
(0.3362)\end{array}$ & $\begin{array}{l}0.1722 \\
(0.2308)\end{array}$ & $\begin{array}{l}-0.0650 \\
(-0.1055)\end{array}$ & $4.7376^{* *}$ & & $\begin{array}{l}67 / 153 \\
(-6.633)^{* * *}\end{array}$ \\
\hline \multirow{2}{*}{$\begin{array}{l}\text { Control } \\
\text { privatization }\end{array}$} & \multirow{2}{*}{ TIE } & Revenue & 151 & $\begin{array}{l}6.7344 \\
(4.8785)\end{array}$ & $\begin{array}{l}3.9197 \\
(9.3645)\end{array}$ & $\begin{array}{l}-2.8146 \\
(4.4861)\end{array}$ & \multicolumn{2}{|l|}{$3.275^{* * *}$} & $\begin{array}{l}61 / 90 \\
(-2.360)^{* * *}\end{array}$ \\
\hline & & Control & 461 & $\begin{array}{l}6.1595 \\
(-11.5499)\end{array}$ & $\begin{array}{l}4.9435 \\
(4.9452)\end{array}$ & $\begin{array}{l}-1.2160 \\
(16.4951)\end{array}$ & $2.751^{* *}$ & 1.174 & $\begin{array}{l}217 / 244 \\
(-1.258)\end{array}$ \\
\hline $\begin{array}{l}\text { Firms with } \\
\text { foreign }\end{array}$ & $\mathrm{OCF} / \mathrm{TD}$ & Foreign & 13 & $\begin{array}{l}0.2378 \\
(0.2697)\end{array}$ & $\begin{array}{l}0.1533 \\
(0.1508)\end{array}$ & $\begin{array}{l}-0.0845 \\
(-0.1190)\end{array}$ & $2.4102^{* *}$ & 1.4041 & $\begin{array}{l}1 / 12 \\
(-14.35)^{* *}\end{array}$ \\
\hline $\begin{array}{l}\text { share } \\
\text { vs }\end{array}$ & & Local & 275 & $\begin{array}{l}0.2358 \\
(0.3560)\end{array}$ & $\begin{array}{l}0.1838 \\
(0.2367)\end{array}$ & $\begin{array}{l}-0.0520 \\
(-0.1193)\end{array}$ & $5.0031^{* *}$ & & $\begin{array}{l}93 / 182 \\
(-5.492)^{* * *}\end{array}$ \\
\hline
\end{tabular}


Table 4 (continued)

\begin{tabular}{|c|c|c|c|c|c|c|c|c|c|}
\hline \multirow{2}{*}{ Sample } & \multirow{2}{*}{ Variable } & & \multirow{2}{*}{$N$} & \multirow{2}{*}{$\begin{array}{l}\text { Median } \\
\text { (mean) } \\
\text { before }\end{array}$} & \multirow{2}{*}{$\begin{array}{l}\text { Median } \\
\text { (mean) } \\
\text { after }\end{array}$} & \multirow{2}{*}{$\begin{array}{l}\text { Median } \\
\text { (mean) } \\
\text { change }\end{array}$} & \multicolumn{2}{|c|}{ Wilcoxon test } & \multirow{2}{*}{$\begin{array}{l}+\mathrm{ve} /-\mathrm{ve} \\
\text { Ratio } \\
\text { (Prop. Z) }\end{array}$} \\
\hline & & & & & & & $\begin{array}{l}\text { Paired } \\
\text { obs. }\end{array}$ & $\begin{array}{l}\text { Bet. } \\
\text { groups }\end{array}$ & \\
\hline \multirow{2}{*}{$\begin{array}{l}\text { Firms } \\
\text { without } \\
\text { foreign } \\
\text { share }\end{array}$} & \multirow[t]{2}{*}{ TIE } & Foreign & 36 & $\begin{array}{l}7.2707 \\
(14.3914)\end{array}$ & $\begin{array}{l}2.5151 \\
(-1.1863)\end{array}$ & $\begin{array}{l}-4.7556 \\
(-15.5776)\end{array}$ & $2.157^{* *}$ & \multirow[t]{2}{*}{0.867} & $\begin{array}{l}16 / 20 \\
(-0.667)\end{array}$ \\
\hline & & Local & 576 & $\begin{array}{l}6.2178 \\
-8.8645\end{array}$ & $\begin{array}{l}4.7604 \\
(6.4869)\end{array}$ & $\begin{array}{l}-1.4574 \\
(15.3514)\end{array}$ & $3.690 * *$ & & $\begin{array}{l}262 / 314 \\
(-2.167)^{* *}\end{array}$ \\
\hline \multirow[t]{2}{*}{$\begin{array}{l}\text { Firms listed } \\
\text { in } 94-95\end{array}$} & \multirow[t]{2}{*}{$\mathrm{OCF} / \mathrm{TD}$} & $94-95$ & 48 & $\begin{array}{l}0.2142 \\
(0.2414)\end{array}$ & $\begin{array}{l}0.1444 \\
(0.1899)\end{array}$ & $\begin{array}{l}-0.0698 \\
(-0.0515)\end{array}$ & \multicolumn{2}{|l|}{$4.5993^{* *}$} & $\begin{array}{l}17 / 31 \\
(-4.949)^{* * *}\end{array}$ \\
\hline & & $96-98$ & 240 & $\begin{array}{l}0.2376 \\
(0.3743)\end{array}$ & $\begin{array}{l}0.1870 \\
(0.2414)\end{array}$ & $\begin{array}{l}-0.0506 \\
(-0.1328)\end{array}$ & $4.5993^{* *}$ & 0.6996 & $\begin{array}{l}77 / 163 \\
(-6.081)^{* *}\end{array}$ \\
\hline \multirow{2}{*}{$\begin{array}{l}\text { Firms listed } \\
\text { in } 96-98\end{array}$} & \multirow[t]{2}{*}{ TIE } & $94-95$ & 107 & $\begin{array}{l}7.5234 \\
(0.5033)\end{array}$ & $\begin{array}{l}3.7915 \\
(-1.3843)\end{array}$ & $\begin{array}{l}-3.7320 \\
(-1.8876)\end{array}$ & $2.979^{* *}$ & \multirow[t]{2}{*}{$2.017^{* *}$} & $\begin{array}{l}40 / 67 \\
(-2.610)^{\text {*** }}\end{array}$ \\
\hline & & $96-98$ & 505 & $\begin{array}{l}5.9360 \\
(-9.1915)\end{array}$ & $\begin{array}{l}4.9771 \\
(7.6077)\end{array}$ & $\begin{array}{l}-0.9588 \\
(16.7992)\end{array}$ & $3.064^{* *}$ & & $\begin{array}{l}238 / 267 \\
(-1.290)\end{array}$ \\
\hline
\end{tabular}

$*(* *)$ Denotes significance at the $10 \%(5 \%)$ level (two-tails).

The median TIE also drops from 6.24 to 4.73 after privatization with a Wilcoxon value of 4.02 , which is statistically significant at the $5 \%$ level. The ratio test also indicates that the number of firms having worse TIE after privatization (334 firms) significantly outnumbers the number of firms having improved TIE after privatisation (278 firms) in the statistical sense. Although the mean TIE values show an opposite situation, the mean TIE value before privatisation being negative makes the comparison less meaningful. Some firms have negative EBIT with low interest expenses before privatization, constituting large negative TIE values that pull the mean TIE to negative.

Subsample figures show that the increase in leverage after privatisation is a general phenomenon across SOEs. However, we do not intend to suggest that increased leverage must be "bad" for reasons mentioned before. In fact, using aggregate, sectorial data of industrial SOEs, Holz (2000) shows that a high liability-asset ratio tends to have a high level of profitability after controlling for the endogeneity of the leverage ratio. We will look into this point later.

\subsection{Employment}

Employment is typically a serious issue in privatising SOEs. Inefficiency of SOEs is partly blamed for lifelong employment policy and lack of well-functioning labor market under a central-planned economy. We are interested in how our sample SOEs behave after privatisation in terms of employment level and employee productivity. After all, the purpose of eliminating redundant workforce is to improve productivity and efficiency. We use three variables to capture the effect, the real sales to employee ratio, the real net profit to employee ratio, and the real EBIT to 
employee ratio. Unfortunately, the firm-level employment figures are very difficult to get and typically scattered around different years. We only use those firms that have both employment figures in their IPO prospectuses and employment figures within three years after listing. As a result, we have only 112 usable firm data for comparison. Panel A of Table 5 shows results.

Surprisingly, the median employment figure increases from 1,478 workers before privatisation to 1,849 workers after privatisation. Also, there are 63 firms exhibiting employment increase and only 49 firms exhibits employment decrease. However, these changes are not statistically significant. More comforting finding is that the productivity improves after privatisation. The real sales per employee increases from Renminbi 105,860 to Renminbi 126,670 with a Wilcoxon value of 1.82 , which is statistically significant at the $10 \%$ level. The real net profit per employee and the real EBIT per employee also increase after privatisation although without statistical significance. Yet, the binomial test does indicate that significantly more firms have productivity increase (in terms of real sales per employee and real EBIT per employee) than productivity decrease after privatisation, as revealed by the ratio figures in the last column of the table. The sample size is too small for us to do any meaningful cross-group comparisons. SIP in China does not lead to massive layoff and instead, it leads to increased employment and higher productivity. However, it is possible that the SIP firms already trimmed down the workforce before going public.

Because the sample size is too small, it prevents us from drawing concrete conclusions. Therefore, we also list out the urban employment figures of SOEs, collectives, and other types of production units across time in Panel B of Table 5 to put things in perspective. Without surprise, SOEs have been the major employers throughout the past 20 years. The employment figure kept increasing but peaked in mid-1990s and began to decline continuously. In fact, in the past five years, SOEs have already layed off 30 million workers. Another major public sector is the Collectives that also had a steady increase in employment till early 1990s and then began to decline. They layed off 15 million workers in the past five years. A sharp contrast is the other production units. Almost without exceptions, these production units have continuous employment increase throughout all these years. One category that is particularly relevant to our sample is the Shareholding Corporations. Since the start of the category in 1993, the employment figures continue to increase except in 1998. In any case, these figures indirectly reflect the fact that as China moves towards the Socialistic market economy, the employment force shifts from the public sector towards the private sector. This also arises from the Chinese government giving SOEs the flexibility to determine their own workforce. As a result, worker layoffs (xia guang) have become a general phenomenon in China but it also constitutes a serious socio-economic problem in China that causes great concern for the government. In the news conferences of the 16th Communist Party Congress, the Chief of State Economic Planning Committee, Zeng Peiyan and the Minister of Social Security, Zhang Zuoyi admitted that unemployment is a very serious problem now in China. SOE restructuring has so far layed off 24-25 million workers. The city unemployment rate reaches $7 \%$ in the end of September this year, which amounts to 
Table 5

Employment statistics

Panel A. Comparison of employment figures and employee productivity

The table presents the number of observations, the mean and median values of the employment level and employee productivity for the average of three years pre- and post-privatization periods, the mean and median change in the employment level and employee productivity value (post-pre), and the tests of significance of the median change. The Wilcoxon $Z$-test is employed to test for any significant change in the median value. The last column shows the number of positive versus negative changes and the proportion $Z$-test on if the proportion of positive change is greater than $50 \%$. Employee productivity is in thousand dollars per employee.

\begin{tabular}{|c|c|c|c|c|c|c|}
\hline Variable & $\begin{array}{l}\text { Number of } \\
\text { observation }\end{array}$ & $\begin{array}{c}\text { Median } \\
\text { (mean) } \\
\text { before }\end{array}$ & $\begin{array}{c}\text { Median } \\
\text { (mean) } \\
\text { after }\end{array}$ & $\begin{array}{c}\text { Median } \\
\text { (mean) } \\
\text { change }\end{array}$ & $\begin{array}{l}\text { Wilcoxon } \\
\text { test }\end{array}$ & $\begin{array}{c}+ \text { ve } /- \text { ve } \\
\text { Ratio } \\
\text { (Prop. Z) }\end{array}$ \\
\hline Employee & 112 & $\begin{array}{c}1478.50 \\
(2427.69)\end{array}$ & $\begin{array}{c}1849.00 \\
(2857.18)\end{array}$ & $\begin{array}{l}370.50 \\
429.49\end{array}$ & 1.0649 & $\begin{array}{c}63 / 49 \\
(1.224)\end{array}$ \\
\hline Real sales/employee & 112 & $\begin{array}{c}105.86 \\
(228.16)\end{array}$ & $\begin{array}{c}126.67 \\
(313.73)\end{array}$ & $\begin{array}{c}20.81 \\
(85.57)\end{array}$ & $1.8254^{*}$ & $\begin{array}{c}70 / 42 \\
(2.721)^{* *}\end{array}$ \\
\hline RNP/employee & 112 & $\begin{array}{c}9.55 \\
(19.76)\end{array}$ & $\begin{array}{c}12.47 \\
(25.19)\end{array}$ & $\begin{array}{c}2.92 \\
(5.43)\end{array}$ & 1.0259 & $\begin{array}{c}60 / 52 \\
(0.844)\end{array}$ \\
\hline REBIT/employee & 97 & $\begin{array}{c}14.871 \\
(30.65)\end{array}$ & $\begin{array}{c}17.018 \\
(41.44)\end{array}$ & $\begin{array}{r}2.147 \\
(10.78)\end{array}$ & 0.4706 & $\begin{array}{c}56 / 41 \\
(1.653)^{*}\end{array}$ \\
\hline
\end{tabular}

Panel B. China urban year-end employment figures (in '0000 units) ${ }^{\mathrm{a}}$

The table presents the urban employment figures by production units. "SOE" are the state-owned units. "Collective" are the collective-owned units. "Coop" are the cooperative units. "Joint Own" are the joint ownership units. "Ltd. Corp" are the limited liability corporations. "Share Holding" are share holding corporations. "Private Ent" are private enterprises. "HK/M/T Funded" are units with funds from Hong Kong, Macau, and Taiwan. "Foreign Funded" are foreign funded units and "Self-employed" are selfemployed individuals.

\begin{tabular}{|c|c|c|c|c|c|c|c|c|c|c|}
\hline & SOE & Collective & Coop. & $\begin{array}{l}\text { Joint } \\
\text { own. }\end{array}$ & $\begin{array}{l}\text { Ltd. } \\
\text { corp }\end{array}$ & $\begin{array}{c}\text { Share } \\
\text { holding }\end{array}$ & $\begin{array}{c}\text { Private } \\
\text { ent. }\end{array}$ & $\begin{array}{c}\mathrm{HK} / \mathrm{M} / \mathrm{T} \\
\text { funded }\end{array}$ & $\begin{array}{l}\text { Foreign } \\
\text { funded }\end{array}$ & $\begin{array}{c}\text { Self- } \\
\text { employed }\end{array}$ \\
\hline 1978 & 7,451 & 2,048 & & & & & & & & 15 \\
\hline 1979 & 7,693 & 2,274 & & & & & & & & 32 \\
\hline 1980 & 8,019 & 2,425 & & & & & & & & 81 \\
\hline 1981 & 8,372 & 2,568 & & & & & & & & 113 \\
\hline 1982 & 8,630 & 2,651 & & & & & & & & 147 \\
\hline 1983 & 8,771 & 2,744 & & & & & & & & 231 \\
\hline 1984 & 8,637 & 3,216 & & & & & & & & 339 \\
\hline 1985 & 8,990 & 3,324 & & 38 & & & & & 6 & 450 \\
\hline 1986 & 9,333 & 3,421 & & 43 & & & & 1 & 12 & 483 \\
\hline 1987 & 9,654 & 3,488 & & 50 & & & & 1 & 20 & 569 \\
\hline 1988 & 9,983 & 3,527 & & 63 & & & & 2 & 29 & 659 \\
\hline 1989 & 10,109 & 3,502 & & 82 & & & & 4 & 43 & 648 \\
\hline 1990 & 10,346 & 3,549 & & 96 & & & 57 & 4 & 62 & 614 \\
\hline 1991 & 10,664 & 3,628 & & 49 & & & 68 & 69 & 96 & 692 \\
\hline 1992 & 10,889 & 3,621 & & 56 & & & 98 & 83 & 138 & 740 \\
\hline 1993 & 10,920 & 3,393 & & 66 & & 164 & 186 & 155 & 133 & 930 \\
\hline 1994 & 10,890 & 3,211 & & 52 & & 292 & 332 & 211 & 195 & 1,225 \\
\hline 1995 & 10,955 & 3,076 & & 53 & & 317 & 485 & 272 & 241 & 1,560 \\
\hline
\end{tabular}


Table 5 (continued)

\begin{tabular}{rrrrrrrrrrc}
\hline & SOE & Collective & Coop. & $\begin{array}{c}\text { Joint } \\
\text { own. }\end{array}$ & $\begin{array}{c}\text { Ltd. } \\
\text { corp }\end{array}$ & $\begin{array}{c}\text { Share } \\
\text { holding }\end{array}$ & $\begin{array}{c}\text { Private } \\
\text { ent. }\end{array}$ & $\begin{array}{c}\text { HK/M/T } \\
\text { funded }\end{array}$ & $\begin{array}{c}\text { Foreign } \\
\text { funded }\end{array}$ & $\begin{array}{c}\text { Self- } \\
\text { employed }\end{array}$ \\
\hline 1996 & 10,949 & 2,954 & & 49 & & 363 & 620 & 265 & 275 & 1,709 \\
1997 & 10,766 & 2,817 & & 43 & & 468 & 750 & 281 & 300 & 1,919 \\
1998 & 8,809 & 1,900 & 136 & 48 & 484 & 410 & 973 & 294 & 293 & 2,259 \\
1999 & 8,336 & 1,652 & 144 & 46 & 603 & 420 & 1,053 & 306 & 306 & 2,414 \\
2000 & 7,878 & 1,447 & 155 & 42 & 687 & 457 & 1,268 & 310 & 332 & 2,136 \\
\hline
\end{tabular}

$*(* *)$ Denotes significance at the 10\% (5\%) level (two-tails).

${ }^{\text {a }}$ Source: China Statistical Yearbook (2001).

14 million people (Ming Pao, November 11, 2002, A22 and November 12, 2002, B11).

\subsection{Cross-sectional test}

Dewenter and Malatesta (2001) point out that the Wilcoxon test does not take into consideration the possible change in the general level of economic activity before and after privatization, which may well be the reason for changes in firm attributes. We follow their approach to use cross sectional regression to re-examine changes in performance, output, and leverage by controlling this possible influential macro variable:

$$
\begin{aligned}
\Delta \mathrm{PP}_{i}=\alpha & +\beta_{1} \Delta \mathrm{GDPGR}_{i}+\beta_{2} \mathrm{SHSE}_{i}+\beta_{3} \mathrm{REG}_{i}+\beta_{4} \mathrm{REV}_{i} \\
& +\beta_{5} \mathrm{FRN}_{i}+\beta_{6} \mathrm{DUM}_{i}+\varepsilon_{i} .
\end{aligned}
$$

The sign " $\Delta$ " is the difference in the three-year averages of the variable in question before and after privatization. PP is the three-year average of the performance proxy and GDPGR is the three-year average of real GDP growth. If the changes in firm performance after privatization documented in Tables $1-4$ are not totally due to a general macroeconomic improvement, the intercept, $\alpha$ would show up with statistical significance in the regression. Most SOEs went through restructuring one or two years before listing in China. Since the exact data on ST, LP, and employee shares during the three years before listing are not available, we cannot directly examine the change in average ST, LP from three years before to three years after the SIP. The dummy variables SHSE, REG, REV, FRN, and DUM96 are used to capture the possible differences in performance changes across the subgroups. SHSE takes the value of one if the firm is listed on the SHSE and zero if it is listed on the SZSE. REG takes the value of one if the firm is in a regulated industry and zero otherwise. REV takes the value of one if the firm is under revenue privatization and zero when under control privatization. FRN takes the value of one if the firm issues foreign shares and zero otherwise. DUM96 takes the value of one if the firm is privatised in 1996 or beyond and zero when privatised before 1996. 
Table 6

Cross-sectional regression analysis on performance change

This table presents empirical results of the cross-sectional regression analysis on the full sample of privatized firms based on the following model:

$$
\Delta \mathrm{PP}_{i}=\alpha+\beta_{1} \Delta \mathrm{GDPGR}_{i}+\beta_{2} \mathrm{SHSE}_{i}+\beta_{3} \mathrm{REG}_{i}+\beta_{4} \mathrm{REV}_{i}+\beta_{5} \mathrm{FRN}_{i}+\beta_{6} \mathrm{DUM}_{i}+\varepsilon_{i} .
$$

PP is the performance proxy. GDPGR is the real gross domestic product growth rate. The difference sign " $\Delta$ " is the average of the three-year post-privatization data minus the average of the three-year preprivatization data of the variable in question, which captures the difference in mean growth of the variable before and after the privatization. SHSE is a dummy variable that takes the value of one if the firm is listed in the SHSE and zero if it is listed in SZSE. REG is a dummy variable that takes the value of one if a firm is in the regulated industry and zero otherwise. REV is a dummy variable that takes the value of one if the government retains more than $50 \%$ of shares in the firm and zero otherwise. FRN is a dummy variable that takes the value of one if a firm also issues foreign shares and zero otherwise. DUM96 is a dummy variable that takes the value of one if a firm was listed during 1996-1998 and zero otherwise. The $t$ statistics are in parenthesis.

\begin{tabular}{lccccccc}
\hline & $\Delta$ RNP & $\Delta$ REBIT & $\Delta$ ROS & $\Delta$ EBITS & $\Delta$ RS & $\Delta$ TIE & $\Delta$ OCF/TD \\
\hline Constant & 0.6311 & 0.2808 & -0.0358 & -0.0544 & 0.2622 & -12.8672 & -0.1059 \\
& $(1.82)^{*}$ & $(1.65)^{*}$ & $(-1.03)$ & $(-1.78)^{*}$ & $(1.74)^{*}$ & $(-0.33)$ & $(-0.86)$ \\
$\Delta$ GDPGR & 0.0326 & 0.0736 & 0.0034 & -0.0005 & 0.02509 & 0.3416 & -0.0380 \\
& $(1.85)^{*}$ & $(2.28)^{* * *}$ & $(0.34)$ & $(-0.06)$ & $(0.55)$ & $(0.03)$ & $(-1.09)$ \\
SHSE & -0.1604 & 0.0728 & -0.0123 & -0.0032 & 0.1415 & 32.5747 & -0.0521 \\
& $(-0.76)$ & $(0.74)$ & $(-0.61)$ & $(-0.18)$ & $(1.67)^{*}$ & $(1.42)$ & $(-0.81)$ \\
REG & 0.5593 & 0.3330 & 0.0188 & -0.0067 & 0.2475 & -8.0429 & -0.0618 \\
& $(2.61)^{* * *}$ & $(1.93)^{*}$ & $(0.44)$ & $(-0.39)$ & $(1.32)$ & $(-0.22)$ & $(-0.75)$ \\
REV & -0.0731 & -0.1073 & 0.0098 & 0.0291 & -0.1517 & -4.9633 & -0.1261 \\
& $(-0.28)$ & $(-0.91)$ & $(0.53)$ & $(0.76)$ & $(-1.67)^{*}$ & $(-0.10)$ & $(-1.01)$ \\
FRN & -0.0041 & -0.0081 & -0.0012 & 0.0096 & -0.0051 & -27.1158 & -0.0053 \\
& $(-0.52)$ & $(-1.62)$ & $(-0.67)$ & $(0.43)$ & $(-1.43)$ & $(-1.52)$ & $(-0.12)$ \\
DUM96 & 0.5825 & 0.4555 & 0.0005 & -0.0486 & 0.4263 & 16.3206 & -0.0981 \\
& $(2.28)^{* * *}$ & $(4.14)^{* * *}$ & $(0.02)$ & $(-0.68)$ & $(4.36)^{* *}$ & $(0.82)$ & $(-1.25)$ \\
Adj. $R^{2}$ & 0.0046 & 0.0296 & -0.0068 & -0.0044 & 0.0358 & -0.0055 & -0.0050 \\
DW & 2.0272 & 1.9325 & 1.9379 & 1.9486 & 1.9187 & 1.8729 & 1.9956 \\
OBS & 634 & 606 & 634 & 614 & 633 & 614 & 288 \\
\hline
\end{tabular}

$*(* *)$ Denotes significance at the $10 \%(5 \%)$ level (two-tails).

The regression results presented in Table 6 generally conform with the results in Tables 1-4. Specifically, the earnings improvements after privatization are significant. The intercepts of the regressions on change in real net profit and change in real operating income are, respectively, 0.63 with a $t$-value of 1.81 and 0.28 with a $t$-value of 1.65 . Both $t$-values are statistically significant at the $10 \%$ level. Similar significant improvement also shows up in real sales. Notice that the change in GDP growth does enter significantly into some of the regressions, but performance improvements are not completely driven by it. Also, the yearly dummy, DUM96 shows that those SOEs privatized later have significantly higher increase in real net profit, real EBIT, and real sales than those privatized early. 


\subsection{Performance after privatization}

In this section, we examine possible performance improvements after privatisation. If privatisation works, its effect should be gradual rather than sudden and immediate. Thus, looking at performance after privatisation should also reveal the impact of privatisation, if any, and can also avoid the manipulation problem. It is argued that the SOEs manipulate accounting data to improve their presentation before their IPO (Wong et al., 1998). If that is the case, performance improvements might not be as significant as they should be.

Megginson et al. (2000) examine 158 SIPs from 33 countries during the period 1981-1997 to see the long-run performance of the share prices. They find statistically significant positive net returns for these firms for all holding periods and for all benchmarks. The adjusted return can also capture the market view of the future prospects of the privatized firms that accounting measures do not. If the market believes that privatization is good for a firm, it should be reflected in the firm's share price. Unfortunately, we cannot do a similar, market-adjusted return analysis in China's case. As mentioned before, almost all stocks listed in China are privatized SOEs so that there are no valid benchmarks of market or industry portfolios to make return adjustments. We can only plot the annual raw returns of our sample firms over time to get a general idea of how these firms perform in the market. But as a reference, we do use the common market index of Hong Kong, the Hang Seng Index to do the return adjustment for the sake of comparison.

Panel A of Fig. 1 shows the time plots of the average raw monthly returns of equally weighted portfolios of firms listed in the same year. Except in 1995, annual returns were positive and tended to increase over time. It is interesting to see that the return subsequent to the year of privatisation tends to be lower except for the firms privatised in 1994. This is consistent with the argument of IPO earnings management. The blip in 1996 may be due to the growing of the speculative bubble in previous years and the subsequent soft landing of China's economy after then Vice Premier Zhu Rongji's "macro-tuning" policy, which successfully brought down the double-digit inflation. The Chinese local investors seem optimistic about the future of the privatized SOEs. However, we have to bear in mind that China's stock market is not very efficient due to too much money of unsophisticated investors chasing after too few stocks controlled under immature securities ordinances. Hence, the high positive returns of these stocks need not truly reflect the market's rational appraisal of the future prospects of the privatized SOEs.

Panel B shows the return plots adjusted by the Hong Kong market return, proxied by the Hang Seng Index (HSI). The situation is roughly the same except that the adjusted returns have a somewhat reverse pattern in the 1998-1999 period. Instead of seeing the raw returns bottomed out in 1998 and started rising in 1999, the adjusted returns actually increased to an average monthly return of 4\% in 1998 and then dropped to around $0 \%$ in 1999 . However, this is mainly due to Hong Kong being badly hit by the Asian Crisis while China was able to shun off from the turmoil.

The wave of currency attack that started in Thailand moved to Hong Kong in 1998 and sank the HSI from 11,000 in March to 6,544 in August, which prompted 
Panel A. Comparison of raw returns

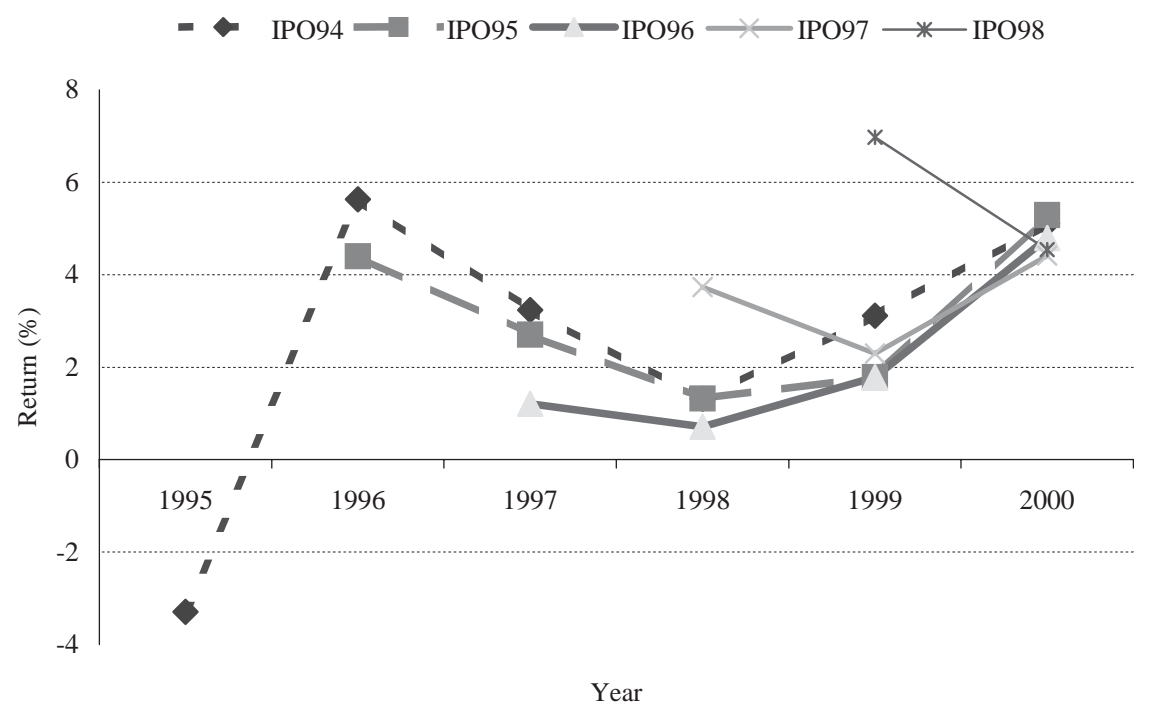

Panel B. Comparison of adjusted returns

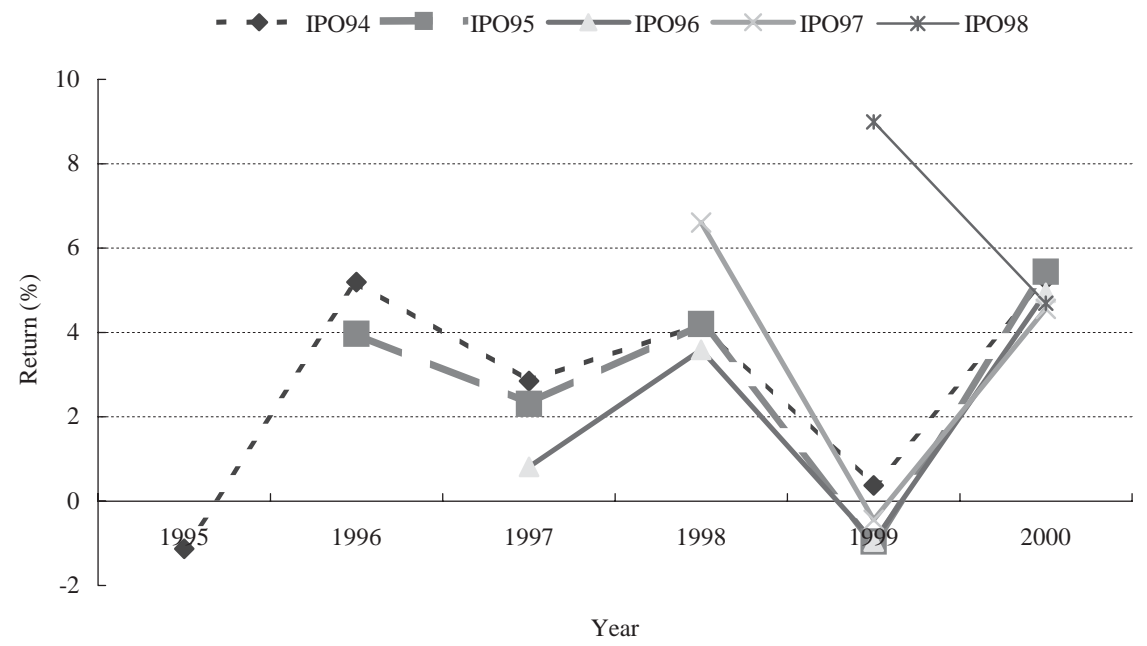

Fig. 1. Comparison of mean monthly return. The figures show raw returns and market-adjusted returns of portfolios of stocks listed in different years.

the Hong Kong government to spend over $\$ 13$ billion to buy up the market. With the collapse of the Long-Term Capital Management, the cut in interest rates by the Fed, and the build up of the TMT bubble, the Index dramatically rebounded and surpassed 17,000 by the end of 1999 before Hong Kong entering into a long-term recession that is unprecedented in its recent history. 
The evidence so far suggests that China's partial privatisation has achieved some success, although the success is rather limited comparing to the evidences shown elsewhere. This could be due to the very nature of China's partial privatization. Many people argue that there is not much real change in corporate governance in China because the government is still the largest shareholder and effective control of the privatized firms. To look into such accusation, we further investigate the linkage between the ownership structure and the performance of SIP firms.

\section{Ownership and performance}

As mentioned before, the unique feature of China's privatization is the government retention of significant portions of state shares in the privatized SOEs. How would this relate to the performance changes of SIP firms we have observed?

\subsection{Pooled regression study}

We use the panel data method to exploit the relation between changes in performance and changes in ownership structure over time after the SOEs were partially privatized. The data cover the same 634 firms for the period 1994-2000. Panel B of Appendix A provides the simple descriptive statistics of each variable across years. Our equation reads

$$
\begin{aligned}
\mathrm{PP}_{i t}= & \alpha_{i t}+\beta_{1} \mathrm{ST}_{i t}\left(\text { or }_{\mathrm{LP}}\right)+\beta_{2} \mathrm{FRN}_{i}+\beta_{3} \mathrm{GDP}_{i t} \\
& +\beta_{4} \mathrm{SIZE}_{i t}+\beta_{5} \mathrm{LEVE}_{i t}+\varepsilon_{i t} .
\end{aligned}
$$

The performance proxies, PP, include ROS and EBITS as defined before. We also include the market-to-book ratio (MBR) of equity, a proxy for Tobin's $q$, as one more measure for firm performance since we use only post-listing data here. Tobin's $q$ is a popular proxy for firm performance (Morck et al., 1988; McConnell and Servaes, 1990, 1995, and others). Our proxy is similar to that used in Chung and Pruitt (1994), Perfect and Wiles (1994), Agrawal and Knoeber (1996), Kang and Stulz (1996), and Clarkson et al. (1997), among others.

The ownership variables, ST, LP, and FRN are the fractions of firm shares owned, respectively, by the government, legal persons, and foreigners after the listing. We examine ST and LP in separate regressions due to their high correlation. Other variables are control variables. GDP is used in the same spirit as in Eq. (2) to control for general changes in economic activities through time. SIZE is the natural logarithm of annual sales revenue, a proxy for firm size. Dewenter and Malatesta (2001) also use the natural logarithm of total assets as size proxy. We have tried this proxy, too and the results are qualitatively the same as using log sales. Large SOEs tend to have larger market share and more market power. They utilize such power better after privatization. However, large SOEs also encounter more government bureaucracy, more redundancy, and bigger agency problems, which are detrimental to a firm's performance. Hence, it is an empirical question if the overall size impacts are positive or negative to firm performance. LEVE is the total debt ratio, LA, which 
controls for any possible leverage effect. In these and subsequent regressions, we use back the more standard leverage measure as the mechanical increase in total asset value due to primary issue of SIP is no longer a concern when using only post-listing data. As discussed before, the debt problem of SOEs is a big issue in China but debt is a cheap capital, too. The final result depends on which effect is dominating.

Since Himmelberg et al. (1999) show that unobserved heterogeneity across firms can generate a spurious correlation between ownership and performance (if the unobserved, exogenous variables are correlated to ownership and performance), we use firm-specific, fixed-effect formulation. Such a specification, with the GDP variable, controls for both year-variant but firm-invariant omitted variables as well as firm-variant but time-invariant omitted variables. On the other hand, their concern on managerial ownership being endogenously determined may not be serious in our case. In China, ST and LP are most likely exogenous because they are created based on government policy, ideology, and quota system, which are not endogenous to the SOE. Hence, fixed effect specification is appropriate. Notice that once individual (or firm-specific) time-invariant variables are controlled, the possible effects of industry are also controlled and so the industrial dummy is not necessary under such formulation.

Since there are many firms in the sample, allowing different firms different intercepts gives messy regression output. To avoid this, all except dummy variables were transformed into their deviation form to "sweep out" the intercept term (see, for example, Bekaert and Harvey, 1997; Domowitz et al., 1997). The White adjustment is used throughout to control for cross-sectional heteroskedasticity.

Table 7 presents the results on MBR, ROS, and EBITS. ST and LP are run separately in the pooled regressions due to their high correlation through time.

The state-ownership variable ST has negative coefficients in all three regressions. Although, only that in the MBR regression bears statistical significance. This suggests that even if partial privatization is better than complete privatisation, as discussed in Section 3 above, the proportion of shares held by the government is too big and hurts the company performance. It should be reduced.

The legal-personal ownership LP, on the other hand, has positive impacts. In the MBR regression, the LP coefficient is 0.36 and in the ROS regression, the coefficient is 0.07 . The $t$-values of both coefficients are marginally significant at the $10 \%$ level. This suggests that the state and legal-person ownership have opposite impacts on SOEs. State ownership has negative results but legal-person ownership can have positive results. Our results are consistent with Qi et al. (2000) but inconsistent with the univariate results for the study of Xu and Wang (1997) and Chen (1998).

Somewhat surprising, foreign ownership (FRN) exhibits significantly positive impact only on MBR but not on ROS and EBITS of the firm. This is consistent with the findings in Table 2. We suggest this is due to the following reason. Those firms that issue foreign shares typically have $61 \%$ of the total ownership of the firm in the form of state and legal-person shares. Foreign shares occupy around $34 \%$ of the ownership only. This is the average figure of the 40 companies in our sample that issue foreign shares. The 2\% (roughly) foreign ownership figure shown in Appendix $\mathrm{A}$ is the average of all 634 companies in our sample. Furthermore, for most listed 
Table 7

Pooled regression analysis of the impact of government ownership on firm performance after listing This table presents empirical results of the pooled firm specific fixed-effect regressions:

$$
\mathrm{PP}_{i t}=\alpha_{i t}+\beta_{1} \mathrm{ST}_{i t}\left(\text { or } \mathrm{LP}_{i t}\right)+\beta_{2} \mathrm{FRN}_{i}+\beta_{3} \mathrm{GDP}_{i t}+\beta_{4} \mathrm{SIZE}_{i t}+\beta_{5} \mathrm{LEVE}_{i t}+\varepsilon_{i t} .
$$

Performance proxies (PP) are MBR, ROS, and EBITS, respectively. MBR is the market value of equity divided by the book value of net assets. ROS is the net income per sales. EBITS is the operating income per sales. ST, LP, and FRN represent the fraction of shares of equity owned by the state, legal persons, and foreigners respectively. GDP is the GDP growth rate. SIZE is the natural logarithm of real total assets in RMB. LEVE is total liability divided by total assets. The pooled sample consists of 634 listed firms in both the Shanghai Stock Exchange (SHSE) and the Shenzen Stock Exchange (SZSE) for 1994-2000. $t$-Values are in parenthesis.

\begin{tabular}{|c|c|c|c|c|c|c|}
\hline \multirow[b]{2}{*}{ ST } & \multicolumn{2}{|c|}{ MBR } & \multicolumn{2}{|c|}{ ROS } & \multicolumn{2}{|c|}{ EBITS } \\
\hline & $\begin{array}{c}-0.8518 \\
(-1.73)^{*}\end{array}$ & & $\begin{array}{l}-0.0535 \\
(-1.17)\end{array}$ & & $\begin{array}{l}-0.0123 \\
(-0.53)\end{array}$ & \\
\hline LP & & $\begin{array}{c}0.3631 \\
(1.76)^{*}\end{array}$ & & $\begin{array}{c}0.0786 \\
(1.72)^{*}\end{array}$ & & $\begin{array}{c}0.0362 \\
(1.54)\end{array}$ \\
\hline FRN & $\begin{array}{l}1.6323 \\
(1.93)^{*}\end{array}$ & $\begin{array}{l}1.7376 \\
(2.05)^{* * *}\end{array}$ & $\begin{array}{l}-0.0324 \\
(-0.63)\end{array}$ & $\begin{array}{l}-0.0189 \\
(-0.36)\end{array}$ & $\begin{array}{l}-0.0293 \\
(-0.56)\end{array}$ & $\begin{array}{c}-0.024 \\
(-0.46)\end{array}$ \\
\hline GDP & $\begin{array}{c}0.7136 \\
(8.57)^{* * *}\end{array}$ & $\begin{array}{c}0.7208 \\
(8.62)^{* * * *}\end{array}$ & $\begin{array}{c}0.0347 \\
(7.94)^{* * *}\end{array}$ & $\begin{array}{c}0.0343 \\
(7.86)^{* * *}\end{array}$ & $\begin{array}{c}0.0298 \\
(5.89)^{* * *}\end{array}$ & $\begin{array}{c}0.0297 \\
(5.90)^{* * * *}\end{array}$ \\
\hline SIZE & $\begin{array}{l}-2.4675 \\
(-6.96)^{* * *}\end{array}$ & $\begin{array}{l}-2.4366 \\
(-6.91)^{* * *}\end{array}$ & $\begin{array}{c}0.0839 \\
(5.28)^{* *}\end{array}$ & $\begin{array}{c}0.0860 \\
(8.33)^{* * *}\end{array}$ & $\begin{array}{c}0.0743 \\
(4.44)^{* *}\end{array}$ & $\begin{array}{c}0.0749 \\
(4.47)^{* * *}\end{array}$ \\
\hline LEVE & $\begin{array}{c}0.1567 \\
(9.59)^{* *}\end{array}$ & $\begin{array}{c}0.1561 \\
(9.58)^{\text {*** }}\end{array}$ & $\begin{array}{l}-0.0067 \\
(-8.29)^{* *}\end{array}$ & $\begin{array}{l}-0.0067 \\
(-8.33)^{* * *}\end{array}$ & $\begin{array}{l}-0.0063 \\
(-7.80)^{* *}\end{array}$ & $\begin{array}{l}-0.0063 \\
(-7.81)^{* * *}\end{array}$ \\
\hline No. of obs. & 2958 & 2958 & 2963 & 2963 & 2956 & 2956 \\
\hline Adj. $R^{2}$ & 0.4477 & 0.4475 & 0.3738 & 0.3744 & 0.3525 & 0.3526 \\
\hline DW & 1.8760 & 1.8809 & 1.9899 & 1.9908 & 1.9753 & 1.9762 \\
\hline
\end{tabular}

Note: $* *$ and $*$ denote two-tailed significance at the $5 \%$ and $10 \%$ level, respectively.

companies, the top 10 shareholders are normally the state and legal persons. Foreign ownership, on the other hand, is much more diffused. Foreign shareholders cannot actually perform a corporate governance role in any meaningful way, let alone posting threat to inefficient, incumbent management of the privatized SOE. That is to say, foreign shareholders tend to be passive investors. As a result, although the market takes higher FRN as a positive sign of firm performance, and hence a higher MBR, the actual performance results (in accounting terms) are weaker than what the market expects.

As for the control variables, the result that higher GDP leads to better firm performance is expected. Size and leverage variables give mixed results. Size has negative impact on MBR, which suggests that the market concerns about bigger agency problems for larger firms and favors downsizing of privatised SOEs. Yet, bigger firms earn economies of scale and market power that, in reality, bring positive impacts to ROS and EBITS. Similarly, leverage has positive impact on MBR, which is consistent with the capital structure theory, but has negative impacts on ROS and EBITS, which indicate that high leverage actually eats up SOEs' earnings. We have also tried regressions to allow nonlinear effect of ST and LP on firm's MBR, ROS, 
and EBITS. The results (not reported here) find only mild inverted U-shape pattern that is available in the US studies on managerial ownership and firm performance (Morck et al., 1988; McConnell and Servaes, 1990; Holderness et al., 1999, among others).

\subsection{Reverse causation}

We have found, somewhat opposite to what we expect, that the effect of privatising SOEs is not as successful as reported in studies on other countries. The retention of too much state ownership after privatization and the ineffectiveness of foreign ownership in governing the privatized SOEs are two possible reasons. But before we jump to such conclusions, we want to consider the possibility of reverse causation. It is possible that the government tends to privatize the better-performing SOEs, as the government can sell more shares at a better price. On the other hand, the government can retain a larger proportion of the shares of a poorly performing firm. This is consistent with the effort to avoid the "drainage of state assets" that is heavily criticized throughout the privatization process. Such drainage occurs when the SOEs sell their shares at prices much lower than their net asset values. SOEs carved out their profitable or potentially profitable lines of businesses before going to IPOs, leaving those parts that perform mainly social functions like schools and nurseries to the state government. However, as argued before, the amount of state ownership is largely based on government policy, ideology, and quota system. Hence, we do not expect that performance is a significant determining factor but, nonetheless, we run the following cross-sectional regression to confirm:

$$
\begin{gathered}
\mathrm{ST}_{i}=\alpha_{i}+\beta_{1} \text { Size }_{i}+\beta_{2} \text { Leverage }_{i}+\beta_{3} \text { Profitability }_{i} \\
+\beta_{4} \mathrm{SHSE}_{i}+\sum_{j} \gamma_{i j} \mathrm{IND}_{i j}+\varepsilon_{i} .
\end{gathered}
$$

There are two formulations of ST. One is the percentage of firm shares owned by the government upon public listing. The other is the three-year average (denoted by "AVEST") of the percentage of firm shares owned by the government after public listing. Profitability is proxied by the three-year average of the accounting profits before listing. If the conjecture of more government retention of nonperforming firms' shares upon privatization is correct, $\beta_{3}$ will be significantly negative. Other independent variables are control variables. Size is proxied by the three-year average of log sales before listing. Leverage is proxied by the three-year average ratio of total debt ratio (LA) before listing. SHSE is a dummy variable that takes the value of one if the firm is listed in the SHSE and zero if it is listed in $\mathrm{SZSE}_{\text {. IND }}$ is a set of industrial dummies to control for industry differences. Since no firm in our sample is in the finance industry and manufacturing is used as a benchmark that captured in the constant in the regression, we have only 13 industry dummies, i.e., $j=1, \ldots, 13$. Appendix B presents the distribution of 634 sample firms across the 14 industries in SHSE and SZSE. To save space, we do not report the coefficient estimates of these industrial dummies in this regression and in the subsequent logit regression. Panel A of Table 8 shows the results. 
Table 8

Ex-ante determinants of privatized SOE's ownership

Two regression results are presented in this table. Panel A reports empirical results of the cross-sectional regression analysis on the ex ante determinants of government ownership based on the following model:

$$
\mathrm{ST}_{i}=\alpha_{i}+\beta_{1} \text { Size }_{i}+\beta_{2} \text { Leverage }_{i}+\beta_{5} \text { Profitability }_{i}+\beta_{4} \text { SHSE }_{i}+\Sigma \beta_{j} \text { Industry Dummy }_{j}+\varepsilon_{i} .
$$

ST (AVEST) is the \%age of (three-year average) firm shares owned by government upon (after) the public listing. Size is proxied by the three-year average of log sales before listing. Leverage is proxied by the threeyear average ratio of long-term liability over equity (LLE) before listing. Profitability is proxied by the three-year average of ROS before listing. SHSE is a dummy variable that takes the value of one if the firm is listed in the SHSE and zero if it is listed in SZSE. There are 13 industry dummy variables. Each takes the value of one if a firm belongs to the respective industry and zero otherwise. But to save space, the figures on industrial dummies are not reported. Panel B reports the Logit regression results on the determinants of issuing foreign shares. A binary variable FGN0 (FGN3) which takes the value of one or zero according to if the firm issues foreign share in year 0 (up to three years after the IPO) or not. The Logit regression is specified as follows:

$$
\mathrm{P}_{i}=F\left(Y_{i}\right)=F\left\{\alpha_{i}+\beta_{1} \text { Size }_{i}+\beta_{2} \text { Leverage }_{i}+\beta_{5} \text { Profitability }_{i}+\beta_{4} \text { SHSE }_{i}+\Sigma \beta_{j} \text { Industry Dummy }_{j}+\varepsilon_{i}\right\} .
$$

$\mathrm{P}$, is the probability that a particular firm issues foreign shares. $F\left(Y_{i}\right)$ is the cumulative distribution of a logistic random variable, $Y_{i}$. This random variable is, in turn, a linear function of another set of variables. The variables are the same as previously defined. To save space, the figures on industrial dummies are not reported. The $t$-statistics are in parenthesis.

\section{Panel A.}

Cross-sectional regression on state shares
Panel B.

Logit regression on foreign shares

\begin{tabular}{|c|c|c|c|c|}
\hline LEVERAGE & $\begin{array}{c}0.2007 \\
(2.44)^{* * *}\end{array}$ & $\begin{array}{l}0.1090 \\
(1.48)\end{array}$ & $\begin{array}{c}-2.8729 \\
(-2.10) * *\end{array}$ & $\begin{array}{c}-2.9311 \\
(-2.18)^{* * *}\end{array}$ \\
\hline ROS & $\begin{array}{l}-0.1113 \\
(-1.49)\end{array}$ & $\begin{array}{l}-0.0861 \\
(-1.28)\end{array}$ & $\begin{array}{l}-0.5242 \\
(-0.45)\end{array}$ & $\begin{array}{l}-0.7875 \\
(-0.64)\end{array}$ \\
\hline SHSE & $\begin{array}{l}0.0035 \\
(0.16)\end{array}$ & $\begin{array}{l}-0.0040 \\
(-0.00)\end{array}$ & $\begin{array}{l}0.3776 \\
(1.02)\end{array}$ & $\begin{array}{l}0.2958 \\
(0.81)\end{array}$ \\
\hline Adj. $R^{2}$ & 0.0233 & 0.0286 & 0.051716 & 0.03258 \\
\hline DW & 1.8874 & 1.8668 & 1.890068 & 1.90093 \\
\hline OBS. & 632 & 632 & 632 & 632 \\
\hline $\begin{array}{l}\text { Log likelihood } \\
\text { OBS with Dep }=1 \\
\text { OBS with Dep }=0\end{array}$ & & & $\begin{array}{c}-122.0457 \\
39 \\
593\end{array}$ & $\begin{array}{c}-124.4406 \\
40 \\
592\end{array}$ \\
\hline
\end{tabular}

\begin{tabular}{rr}
\hline FGN0 & \multicolumn{1}{c}{ FGN3 } \\
-16.0087 & -15.6480 \\
$(-6.59)^{* * *}$ & $(-6.54)^{* *}$ \\
& \\
1.1191 & 1.1014 \\
$(6.13)^{* * *}$ & $(6.13)^{* *}$
\end{tabular}

$*(* *)$ Denotes significance at the $10 \%(5 \%)$ level. 
The results do confirm that the profitability, as proxied by ROS, is not related to the amount of state-share ownership. The $t$-values are too small to claim statistical significance. Hence, there is no evidence that SOE profitability prior to privatization affects the government's consideration of how much ownership to retain after its privatization. Using EBITS to proxy for profitability gives qualitatively the same results both in this regression as well as the following logit regression. The determining factors actually are the size and the leverage of the firm. When the size of a firm increases by $1 \%$, the government retains $0.04 \%$ more of the state shares in the year of listing and $0.02 \%$ more each year on average in the next three years after listing. Similarly, a percentage increase in the total debt ratio leads the government to retain $0.20 \%$ more shares in the year of listing and $0.10 \%$ for the next three years on average.

For the sake of completeness, we also investigate if profitability could be a factor inducing privatized SOEs to issue foreign shares, although it is hard to conceive that poorly performing firms would issue more foreign shares. We run the following logit model:

$$
\begin{aligned}
\mathrm{P}_{i}=F\left(Y_{i}\right)= & F\left(\alpha_{i}+\beta_{1} \text { Profitability }_{i}+\beta_{2} \text { Size }_{i}+\beta_{5} \text { Leverage }_{i}\right. \\
& \left.+\sum_{j} \gamma_{i j} \mathrm{IND}_{i j}+\varepsilon_{i}\right) .
\end{aligned}
$$

$\mathrm{P}$ is the probability that a particular firm issues foreign shares. $F\left(Y_{i}\right)$ is the cumulative distribution of a logistic random variable, $Y_{i}$, which takes a binary value. It takes the value of one or zero according to whether the firm issues foreign shares in the year of listing or not. It is assumed to be a linear function of some specified variables. The specified variables are those used in Eq. (3) and are so defined. The results are presented in Panel $\mathrm{B}$ of Table 8 . They show that profitability and foreign ownership are not related. The determining factors are again firm size and leverage. Essentially, there is a higher probability for large firms and firms with lower leverage level to issue foreign shares. It is conceivable as only well-known firms with low leverage can be sold to foreign investors.

\section{Conclusion}

China's SOE reform has been underway for over 20 years, yet rigorous evaluations of the success of the reform movement are limited and without consensus. Our comprehensive study on SIP firms fills the void. We begin our analysis by contrasting the accounting measures of an SOE's performance before and after privatization. We find evidence of improvements in earnings, real sales, and employee productivity up to three years after privatisation. However, both return on sales and earning on sales decline after privatization. Although stock returns show some mild improvements up to five years after the SIP, it could be partly driven by the excessive speculations of Chinese local investors. The more comforting fact is that recently privatized SOEs are of higher quality and indicate more improvements after privatization. 
Regarding the impact of ownership structure on firm performance, Young and McGuiness (2001) argue that the predominance of nontradable shares makes only a minority of SOE's shares subject to market scrutiny and hence the impact would be minimal. However, we find that different ownership structures do have impact on performance across firms and over time after a SIP. Specifically, state shares and legal-person shares have opposite impacts on a firm's performance, despite the fact that legal-persons are mostly state-owned in nature. In simple words, state shares are "bad" and legal-person shares are "good" for privatized SOEs. This is consistent with the argument by Che and Qian (1998) and Jin and Qian (1998) that even different types of government ownership can have vastly different impacts on firm performance. This is also consistent with the results of Qi et al. (2000).

Although foreign ownership shows a positive impact on firm's market-to-book ratio, it shows no significant impact on other performance measures. A recent clinical study by Bortolotti et al. (2001) on privatized firms in the telecommunications industry over 25 countries finds that the firm performance is positively related to US listing but negatively related to UK listing. In fact, telecommunications companies tend to seek foreign listing. Bortolotti et al. (2000) suggest that companies exposed to global competition are more eager to do so. Other than industrial sector, government's political ideology, the stage of economic development, public finance situation, openness of the economy, among other factors are also found in their paper as the causes for governments to sell SIPs to foreign investors. Although that is a cross-listing situation, which is different from our case here, it shows that the impact of foreign ownership on the performance of SIP firms is a complex issue.

All in all, share issue privatisation program in China has only limited success. As the previous minister of the State Economic and Trade Commission (SETC), Sheng Huaren once commented that the overall profitability of SOEs is still weak and "many deep-seated contradictions and problems existing in the SOE reform and development have not yet been solved" ( $\mathrm{Li}, 2001)$. We argue that the main problem lies with the ownership structure that prevents corporate governance to be effective. Essentially, the government still keeps a major control on the partially privatised SOEs so that non-state shareholders who can play a more active and positive role on the SOEs do not have either the power or the incentive to do so. The implications of our findings hence are clear. First, state shares should be further reduced. Second, a certain level of legal-person shares is good. Third, more foreign institutional shareholders are needed as their positive impacts are weak at the current stage.

Recently, the Chinese government has consecutively released three important documents to provide a new direction to SOE reform that are in the spirit of our suggestions. On September 28, CSRC announced the guidelines for takeovers and mergers of listed companies. In early November, CSRC, the Ministry of Finance, and the State Economic and Trade Commission, with the approval of the State Council, made a joint announcement that foreign investors will be allowed to buy nontradable state-owned shares and legal-person shares of listed SOEs (Hong Kong Economic Journal, November 4, 2002, p. 5). Few days later, CSRC and the People's Bank of China jointly announced that foreign institutional investors could apply to become qualified investors, QFII. Once approved by market regulators, QFII will be 
permitted to conduct limited investments in A shares and in government, corporate and convertible bonds. QFII won't be allowed to purchase more than $10 \%$ of the shares in any single Chinese company. The largest stake a group of foreign investors can hold in a Chinese company will be $20 \%$ (Asian Wall Street Journal, November 8 , 2002, p. 1). However, important issues such as whether the purchased state-owned and legal-person shares will be tradable and whether the invested capital is free to be repatriated out need to be addressed. According to a report of Merrill Lynch, the QFII policy will attract \$5 billion capital inflow in the first year of its implementation (Hong Kong Economic Journal, November 9, 2002, p. 5). Then, we can see the effectiveness of such policies in attracting foreign capital in general and in making use of foreign institutional investors to revitalize the SOEs in particular.

\section{Appendix A. Distribution of 634 sample firms across industries and over listing years}

The distribution of sample firms across industries and listing years is presented in Table 9.

Table 9

\begin{tabular}{|c|c|c|c|c|c|c|}
\hline & 1994 & 1995 & 1996 & 1997 & 1998 & All years \\
\hline \multicolumn{7}{|c|}{ Panel A. Firms listed on the Shanghai Stock Exchange } \\
\hline Health Care & 4 & 2 & 5 & 8 & 2 & 21 \\
\hline Media & 1 & & & & 1 & 2 \\
\hline Energy & 1 & & 5 & 2 & 4 & 12 \\
\hline Retail & 14 & & 13 & 5 & 1 & 33 \\
\hline Agriculture & 2 & & 8 & 9 & 7 & 26 \\
\hline Basic Materials & 9 & 1 & 21 & 22 & 15 & 68 \\
\hline Utilities & 3 & & 4 & 5 & 2 & 14 \\
\hline Services & 4 & 1 & 6 & 7 & 1 & 19 \\
\hline Property & & & 1 & & & 1 \\
\hline Multi-industry & 1 & & 1 & & 1 & 3 \\
\hline Manufacturing & 22 & 6 & 24 & 15 & 12 & 79 \\
\hline Transport & & 1 & 5 & 4 & 2 & 12 \\
\hline Technology & 2 & 1 & 7 & 7 & 2 & 19 \\
\hline Telecom & & & 2 & 1 & 2 & 5 \\
\hline Total & 63 & 12 & 102 & 85 & 52 & 314 \\
\hline
\end{tabular}

Panel B. Firms listed on the Shenzhen Stock Exchange

Health Care

Media

Energy

Retail

Agriculture

Basic Materials

Utilities

Services

$\begin{array}{ll}1 & \\ 1 & \\ 2 & 1 \\ 4 & \\ 6 & 1 \\ 5 & \\ 2 & 1\end{array}$

$\begin{array}{rrrr}11 & 8 & 2 & 22 \\ 5 & 3 & 2 & 0 \\ 9 & 8 & & 11 \\ 5 & 12 & 6 & 20 \\ 25 & 36 & 15 & 83 \\ 1 & 3 & 1 & 10 \\ 9 & 7 & 4 & 23\end{array}$


Table 9 (continued)

\begin{tabular}{lcccrrr}
\hline & 1994 & 1995 & 1996 & 1997 & 1998 & All years \\
\hline $\begin{array}{l}\text { Property } \\
\text { Multi-industry }\end{array}$ & 7 & 1 & 2 & 1 & & 11 \\
Manufacturing & 5 & 2 & 25 & 23 & 17 & 0 \\
Transport & 1 & 1 & & 2 & 3 & 72 \\
Technology & 6 & 2 & & 14 & 2 & 30 \\
Telecom & & & & 4 & & 4 \\
Total & 40 & 9 & & 121 & 52 & 320 \\
\hline
\end{tabular}

\section{Appendix B. Summary statistics of ownership distribution and other pooled regression variables}

Table 10 presents the summary statistics of the pooled regression variables.

Table 10

MBR is the market value of equity divided by the book value of net assets. ROS, and EBITS are net income and EBIT divided by the net sales respectively. ST, LP and FRN are the shares (in percent) of equity owned by the state, legal persons, and foreigners respectively. SALE is the real operating sales in million RMB. LEVE is the book value of debt divided by the book value of total assets.

\begin{tabular}{|c|c|c|c|c|c|c|c|}
\hline Variables & Sample pd. & Obs. & Mean & Median & Minimum & Maximum & Std. dev. \\
\hline \multicolumn{8}{|c|}{ Panel A. Figures in aggregate (1994-2000) } \\
\hline MBR & 1994-2000 & 2,958 & 5.2365 & 4.1615 & 0.3206 & 94.6194 & 5.3712 \\
\hline ROS & & 2,963 & 0.1123 & 0.1096 & -2.9557 & 2.9926 & 0.2730 \\
\hline EBITS & & 2,956 & 0.1625 & 0.1567 & -2.9432 & 2.0878 & 0.2758 \\
\hline ST & & 2,983 & 30.5878 & 31.3050 & 0.0000 & 84.9850 & 26.9422 \\
\hline LP & & 2,983 & 32.1664 & 26.1502 & 0.0000 & 90.7160 & 27.1756 \\
\hline FRN & & 2,983 & 2.2928 & 0.0000 & 0.0000 & 49.9391 & 8.4357 \\
\hline SALE & & 2,978 & 410.80 & 207.35 & 0.43 & $9,012.73$ & 689.98 \\
\hline LA & & 2,983 & 0.4423 & 0.4400 & 0.0055 & 2.8612 & 0.2008 \\
\hline \multicolumn{8}{|c|}{ Panel B. Figures in various sample periods } \\
\hline MBR & 1994 & 103 & 2.8144 & 2.2777 & 0.6204 & 16.5819 & 1.8947 \\
\hline ROS & & 103 & 0.1616 & 0.1115 & 0.0061 & 0.8906 & 0.1461 \\
\hline EBITS & & 93 & 0.2049 & 0.1545 & 0.0349 & 0.8051 & 0.1575 \\
\hline ST & & 103 & 34.7648 & 36.4069 & 0.0000 & 79.2774 & 28.3575 \\
\hline LP & & 103 & 31.3202 & 23.4390 & 0.0000 & 90.7160 & 28.6430 \\
\hline FRN & & 103 & 4.1945 & 0.0000 & 0.0000 & 47.0588 & 10.6329 \\
\hline SALE & & 103 & 347.64 & 231.17 & 17.38 & $2,865.71$ & 378.77 \\
\hline LA & & 103 & 0.4076 & 0.4139 & 0.0055 & 0.8593 & 0.1730 \\
\hline MBR & 1995 & 124 & 2.3835 & 2.0427 & 0.5713 & 10.1155 & 1.2483 \\
\hline ROS & & 124 & 0.1038 & 0.0782 & -1.7998 & 1.5535 & 0.2510 \\
\hline EBITS & & 124 & 0.1523 & 0.1228 & -1.5428 & 1.4029 & 0.2355 \\
\hline ST & & 124 & 34.2162 & 36.7325 & 0.0000 & 79.2774 & 27.0840 \\
\hline LP & & 124 & 30.0040 & 22.8681 & 0.0000 & 90.7160 & 27.4234 \\
\hline FRN & & 124 & 4.0369 & 0.0000 & 0.0000 & 47.0588 & 10.5346 \\
\hline SALE & & 124 & 357.19 & 194.03 & 3.61 & $3,951.67$ & 497.30 \\
\hline LA & & 124 & 0.4812 & 0.4913 & 0.0571 & 0.8629 & 0.1526 \\
\hline
\end{tabular}


Table 10 (continued)

\begin{tabular}{|c|c|c|c|c|c|c|c|}
\hline Variables & Sample pd. & Obs. & Mean & Median & Minimum & Maximum & Std. dev. \\
\hline MBR & 1996 & 324 & 4.4081 & 4.1413 & 0.4983 & 15.9853 & 1.8431 \\
\hline ROS & & 324 & 0.1377 & 0.1140 & -1.3438 & 0.9318 & 0.1754 \\
\hline EBITS & & 324 & 0.1943 & 0.1676 & -0.9389 & 1.2898 & 0.1836 \\
\hline ST & & 324 & 32.1002 & 34.4829 & 0.0000 & 79.5997 & 26.2998 \\
\hline LP & & 324 & 31.9532 & 25.2881 & 0.0000 & 90.7160 & 26.5812 \\
\hline FRN & & 324 & 2.7932 & 0.0000 & 0.0000 & 47.0588 & 9.1383 \\
\hline SALE & & 324 & 280.32 & 142.40 & 9.86 & $5,839.74$ & 456.74 \\
\hline LA & & 324 & 0.4446 & 0.4588 & 0.0759 & 0.9272 & 0.1614 \\
\hline MBR & 1997 & 528 & 4.9714 & 4.1738 & 0.5269 & 61.5137 & 4.1464 \\
\hline ROS & & 528 & 0.1517 & 0.1283 & -1.8430 & 1.7772 & 0.2064 \\
\hline EBITS & & 528 & 0.1951 & 0.1647 & -1.3826 & 2.0878 & 0.2018 \\
\hline ST & & 530 & 33.4297 & 36.9483 & 0.0000 & 84.9850 & 27.0252 \\
\hline LP & & 530 & 29.6133 & 22.3376 & 0.0000 & 86.3763 & 26.7674 \\
\hline FRN & & 530 & 2.2419 & 0.0000 & 0.0000 & 48.2120 & 8.4198 \\
\hline SALE & & 529 & 344.37 & 174.42 & 3.98 & $8,538.57$ & 617.44 \\
\hline LA & & 530 & 0.4163 & 0.4198 & 0.0184 & 0.9941 & 0.1723 \\
\hline MBR & 1998 & 632 & 4.9289 & 3.9243 & 0.3206 & 93.4229 & 6.8037 \\
\hline ROS & & 631 & 0.1180 & 0.1224 & -2.2939 & 1.6918 & 0.2837 \\
\hline EBITS & & 632 & 0.1696 & 0.1721 & -2.9432 & 1.7282 & 0.3025 \\
\hline ST & & 634 & 29.2842 & 29.2732 & 0.0000 & 84.9850 & 27.4049 \\
\hline LP & & 634 & 33.7056 & 29.5196 & 0.0000 & 86.3763 & 27.7748 \\
\hline FRN & & 634 & 2.0366 & 0.0000 & 0.0000 & 48.2120 & 8.0727 \\
\hline SALE & & 634 & 380.80 & 196.93 & 8.05 & $6,497.36$ & 614.10 \\
\hline LA & & 634 & 0.4197 & 0.4168 & 0.0232 & 1.0912 & 0.1777 \\
\hline MBR & 1999 & 625 & 4.9683 & 4.0423 & 0.5527 & 74.7865 & 4.4029 \\
\hline ROS & & 627 & 0.0972 & 0.1061 & -2.5498 & 1.9180 & 0.2851 \\
\hline EBITS & & 628 & 0.1542 & 0.1572 & -1.9184 & 1.9559 & 0.2737 \\
\hline ST & & 634 & 29.3094 & 29.1925 & 0.0000 & 84.9850 & 26.9596 \\
\hline LP & & 634 & 33.0567 & 29.4475 & 0.0000 & 86.3763 & 27.2789 \\
\hline FRN & & 634 & 2.0114 & 0.0000 & 0.0000 & 49.9391 & 8.1093 \\
\hline SALE & & 634 & 444.73 & 233.54 & 1.75 & $5,965.10$ & 699.18 \\
\hline LA & & 634 & 0.4478 & 0.4416 & 0.0184 & 2.0170 & 0.2017 \\
\hline MBR & 2000 & 622 & 7.4449 & 5.6871 & 0.9522 & 94.6194 & 6.7478 \\
\hline ROS & & 626 & 0.0692 & 0.0862 & -2.9557 & 2.9926 & 0.3448 \\
\hline EBITS & & 627 & 0.1154 & 0.1301 & -2.8996 & 1.5297 & 0.3486 \\
\hline ST & & 634 & 28.6327 & 27.8646 & 0.0000 & 84.9785 & 26.1874 \\
\hline LP & & 634 & 32.5404 & 29.3812 & 0.0000 & 86.3763 & 26.7585 \\
\hline FRN & & 634 & 1.9670 & 0.0000 & 0.0000 & 49.9391 & 7.8168 \\
\hline SALE & & 630 & 550.61 & 268.72 & 0.43 & $9,012.73$ & 920.66 \\
\hline LA & & 634 & 0.4781 & 0.4633 & 0.0247 & 2.8612 & 0.2523 \\
\hline
\end{tabular}

\section{References}

Agrawal, A., Knoeber, C., 1996. Firm performance and mechanisms to control agency problems between managers and shareholders. Journal of Financial and Quantitative Analysis 31, 377-397.

Bailey, W., 1994. Risk and return on China's new stock markets: some preliminary evidence. Pacific Basin Finance Journal 2, 243-260. 
Barberis, N., Boycko, M., Shleifer, A., Tsukanova, N., 1996. How does privatization work? Evidence from the Russian shops. Journal of Political Economy 104, 764-790.

Bekaert, G., Harvey, C., 1997. Emerging equity market volatility. Journal of Financial Economics 43, 2977.

Berenson, M.L., Levine, D.M., 1998. Business Statistics: A First Course. Prentice-Hall, Englewood Cliffs, NJ.

Biais, B., Perotti, E., 2002. Machiavellian privatization. American Economic Review 92, 240-258.

Boardman, A., Vining, A.R., 1989. Ownership and performance in competitive environments: a comparison of the performance of private, mixed, and state-owned enterprises. Journal of Law and Economics 32, 1-33.

Bortolotti, B., Fantini, M., Scarpa, C., 2000. Why do governments sell privatised companies abroad? Foundazione Eni Enrico Mattei Working Paper No. 23.

Bortolotti, B., D'Souza, J., Fantini, M., Megginson, W., 2001. Sources of performance improvement in privatised firms, A clinical study of the global telecommunications industry. Foundazione Eni Enrico Mattei Working Paper No. 26.

Bös, D., 1991. Privatization: A Theoretical Treatment. Clarendon Press, Oxford, England.

Boubakri, N., Cosset, J., 1998. The financial and operating performance of newly privatized firms: evidence from developing countries. Journal of Finance 53, 1081-1110.

Boycko, M., Shleifer, A., Vishny, R.W., 1994. Voucher privatisation. Journal of Financial Economics 35, 249-266.

Boycko, M., Shleifer, A., Vishny, R.W., 1996. A theory of privatisation. Economic Journal 106, 309-319.

Caves, D.W., Christensen, L.R., 1980. The relative efficiency of public and private firms in a competitive environment: the case of Canadian railroads. Journal of Political Economy 88, 958-976.

Che, J., Qian, Y., 1998. Insecure property rights and government ownership of firms. Quarterly Journal of Economics 113, 467-496.

Chen, Y., 1998. Ownership structure and corporate performance: some Chinese evidence. Unpublished working paper, San Francisco State University.

Chung, K.H., Pruitt, S.W., 1994. A simple approximation of Tobin's q. Financial Management 23, $70-74$.

Clarkson, P.M., Satterly, A., Richwhite, F., 1997. Australian evidence on the pricing of estimation risk. Pacific-Basin Finance Journal 5, 277-295.

Cornelli, F., Li, D.D., 1997. Large shareholders, private benefits of control, and optimal schemes of privatisation. Rand Journal of Economics 28, 585-604.

Dewenter, K., Malatesta, P.H., 2001. State-owned and privately owned firms: an empirical analysis of profitability, leverage, and labor intensity. American Economic Review 91, 320-334.

Djankov, S., Murrell, P., 2000. Enterprise restructuring in transition: a quantitative survey. Unpublished working paper, University of Maryland.

Domowitz, I., Glen, J., Madhavan, A., 1997. Market segmentation and stock prices: evidence from an emerging market. Journal of Finance 52, 1059-1085.

D'Souza, J., Megginson, W.L., 1999. The financial and operating performance of newly privatized firms in the 1990s. Journal of Finance 54, 1397-1438.

D'Souza, J., Megginson W.L., Nash, R., 2000. Determinants of performance improvements in privatized firms: the role of restructuring and corporate governance. Unpublished working paper.

Dyck, I.J.A., 1997. Privatization in Eastern Germany: management selection and economic transition. American Economic Review 87, 565-597.

Frydman, R., Pistor, K., Rapaczynski, A., 1996. Exit and voice after mass privatization: the case of Russia. European Economic Review 40, 581-588.

Frye, T., Shleifer, A., 1997. The invisible hand and the grabbing hand. American Economic Review 87, 354-358.

Gibson, C., 1995. Financial Statement Analysis: Using Financial Accounting Information, 6th Edition. South-Western College Publishing, Cincinnati, OH.

Groves, T., Hong, Y., McMillan, J., Naughton, B., 1994. Autonomy and incentives in Chinese state enterprises. Quarterly Journal of Economics 109, 183-211. 
Himmelberg, C.P., Hubbard, G.R., Palia, D., 1999. Understanding the determinants of managerial ownership and the link between ownership and performance. Journal of Financial Economics 53, 353384.

Hingorani, A., Lehn, K., Makhija, A.K., 1997. Investor behavior in mass privatization: the case of the Czech voucher scheme. Journal of Financial Economics 44, 349-396.

Holderness, C., Kroszner, R., Sheehan, D., 1999. Were the good old days that good? Changes in managerial stock ownership since the great depression. Journal of Finance 54, 435-470.

Holz, C.A., 2000. The impact of the liability-asset ratio on profitability in China's industrial state-owned enterprises. China Economic Review 13, 1-26.

Hu, G.J., Goergen, M., 2001. A study of ownership concentration control and evolution in Chinese IPOs. Unpublished working paper, Manchester School of Management, England.

Jefferson, G., 1998. China's state enterprises: public goods, externalities, and Coase. American Economic Review 88, 428-432.

Jin, H., Qian, Y., 1998. Public versus private ownership of firms: evidence from rural China. Quarterly Journal of Economics 113, 773-808.

Kang, J., Stulz, R.M., 1996. How different is Japanese corporate finance? An investigation of the information content of new security issues. Review of Financial Studies 9, 109-139.

Kazmier, L.J., Pohl, N.F., 1984. Basic Statistics for Business and Economics, 2nd Edition. McGraw-Hill, New York.

Kole, S.R., Mulherin, J.H., 1997. The government as shareholder: a case from the US. Journal of Law and Economics 40, 1-22.

La Porta, R., Lopez-de-Dilanes, F., Shleifer, A., Vishny, R., 1998. Law and Finance. Journal of Political Economy 106, 1113-1155.

La Porta, R., Lopez-de-Dilanes, F., Shleifer, A., Vishny, R., 1999. Corporate ownership around the world. Journal of Finance 44, 471-517.

La Porta, R., Lopez-de-Dilanes, F., Shleifer, A., Vishny, R., 2000. Investor protection and corporate governance. Journal of Financial Economics 58, 3-27.

Li, R., 2001. Three-year target for SOE reform reached. Beijing Review 44, 19-21.

Lin, C., 2000. Corporatisation and corporate governance in China's economic transition. Unpublished working paper, University of Oxford, England.

Lin, J., Cai, F., Li, Z., 1998. Competition, policy burdens, and state-owned enterprise reform. American Economic Review 88, 422-427.

Lipton, D., Sachs, J., Summers, L.H., 1990. Privatization in Eastern Europe: the case of Poland; Comments and discussion. Brookings Papers on Economic Activity 2, 293-341.

Liu, W., Gao, M., 1999. Studies on China's Economic Development. Shanghai Far East Press, Shanghai.

Ma, J., Liu, H., 2000. Review and Prospects for Reform at China's SOEs. Capital Economic and Trade University Press, Beijing.

Martin, S., Parker, D., 1995. Privatization and economic performance throughout the UK business cycle. Managerial and Decision Economics 16, 225-237.

McConnell, J.J., Servaes, H., 1990. Additional evidence on equity ownership and corporate value. Journal of Financial Economics 27, 595-612.

McConnell, J.J., Servaes, H., 1995. Equity ownership and the two faces of debt. Journal of Financial Economics 39, 131-157.

Megginson, W.L., Neffer, J.M., 2001. From state to market: a survey of empirical studies on privatization. Journal of Economic Literature 39, 321-389.

Megginson, W.L., Nash, R.C., Randenborgh, M.V., 1994. The financial and operating performance of newly privatized firms: an international empirical analysis. Journal of Finance 49, 403-452.

Megginson, W.L., Nash, R.C., Netter, J.M., Schwartz, A.L., 2000. The long-run return to investors in share issue privatization. Financial Management 29, 67-77.

Mok, H.M.K., 1995. The evolution of China's stock market. In: Lo, C.K., Yuen, T.K. (Eds.), China Review 1995. Chinese University Press, Beijing, pp. 1-14.

Mok, H.M.K., Hui, Y.V., 1998. Underpricing and the aftermarket performance of IPOs in Shanghai, China. Pacific-Basin Finance Journal 6, 453-474. 
Morck, R., Shleifer, A., Vishny, R.W., 1988. Management ownership and market valuation: an empirical analysis. Journal of Financial Economics 20, 293-315.

Perfect, S.B., Wiles, K.W., 1994. Alternative constructions of Tobin's q: an empirical comparison. Journal of Empirical Finance 1, 313-341.

Perotti, E.C., 1995. Credible privatization. American Economic Review 85, 847-859.

Pohl, G., Andersen, R., Djankov, S., 1997. Privatization and restructuring in Central and Eastern Europe: evidence and policy options. World Bank technical paper No. 368.

Qi, D., Wu, W.Y., Zhang, H., 2000. Ownership structure and corporate performance of partially privatized Chinese SOE firms. Pacific Basin Finance Journal 587-610.

Schmitz, P., 2000. Partial privatization and incomplete contracts: the proper scope of government reconsidered. FinanzArchiv 57, 394-411.

Shleifer, A., Vishny, R., 1997. A survey of corporate governance. Journal of Finance 42, 737-783.

Stiglitz, J., 1997. The role of government in economic development. In: Bruno, M., Pleskovic, B. (Eds.), Annual World Bank Conference on Development Economics 1996. World Bank, Washington, DC, pp. $11-23$.

Sun, Q., Tong, W., 2000. The effect of market segmentation on stock prices: the China syndrome. Journal of Banking and Finance 24, 1875-1902.

Tian, G.L., 1999. Performance of mixed enterprises, state shareholding and agency cost. Unpublished working paper, London Business School.

Vining, A.R., Boardman, A.E., 1992. Ownership versus competition: efficiency in public enterprises. Public Choice 73, 205-239.

Wong, T.J., Teoh, S.H., Welch, I., 1998. Earnings management and long-term under-performance of initial public offerings. Journal of Finance 53, 1935-1974.

Wortzel, H., Wortzel, L., 1989. Privatization: not the only answer. World Development 633-641.

Wu, X. (Ed.), 1997. Research Report on Debt Restructuring of China's State Sector. China Financial Press, Beijing.

Xu, X., Wang, Y., 1997. Ownership structure, corporate governance, and corporate performance. Policy Research Working Paper 1794, The World Bank, Washington, DC.

Young, M., McGuiness, P., 2001. The missing link: why stock markets have been ineffective in Chinese SEO reform. Business Horizons 44, 55-62.

Yu, Q., Cheng, Y., 2001. Market reactions to dividend announcements in emerging market: new evidence from China. Unpublished working paper, Fudan University and National University of Singapore. 